This document was prepared in conjunction with work accomplished under Contract No. DE-AC09-96SR18500 with the U. S. Department of Energy.

\title{
DISCLAIMER
}

This report was prepared as an account of work sponsored by an agency of the United States Government. Neither the United States Government nor any agency thereof, nor any of their employees, nor any of their contractors, subcontractors or their employees, makes any warranty, express or implied, or assumes any legal liability or responsibility for the accuracy, completeness, or any third party's use or the results of such use of any information, apparatus, product, or process disclosed, or represents that its use would not infringe privately owned rights. Reference herein to any specific commercial product, process, or service by trade name, trademark, manufacturer, or otherwise, does not necessarily constitute or imply its endorsement, recommendation, or favoring by the United States Government or any agency thereof or its contractors or subcontractors. The views and opinions of authors expressed herein do not necessarily state or reflect those of the United States Government or any agency thereof. 


\section{IMPACT OF SPHERICAL FRIT BEADS ON SIMULATED DWPF SLURRIES (U)}

M. E. Smith

M. E. Stone

D. H. Miller

September 2005

Immobilization Technology Section Savannah River National Laboratory Aiken, SC 29808

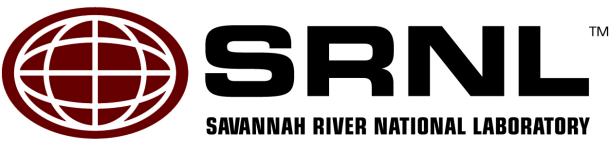

Prepared for the U.S. Department of Energy Under Contract Number DEAC09-96SR18500 


\section{DISCLAIMER}

This report was prepared by Westinghouse Savannah River Company (WSRC) for the United States Department of Energy under Contract No. DE-AC09-96SR18500 and is an account of work performed under that contract. Neither the United States Department of Energy, nor WSRC, nor any of their employees makes any warranty, expressed or implied, or assumes any legal liability or responsibility for the accuracy, completeness, or usefulness, of any information, apparatus, or product or process disclosed herein or represents that its use will not infringe privately owned rights. Reference herein to any specific commercial product, process, or service by trademark, name, manufacturer or otherwise does not necessarily constitute or imply endorsement, recommendation, or favoring of same by WSRC or by the United States Government or any agency thereof. The views and opinions of the authors expressed herein do not necessarily state or reflect those of the United States Government or any agency thereof.

\section{Printed in the United States of America}

Prepared For

U.S. Department of Energy 
Key Words: Frit, Beads, DWPF

Retention: Permanent

\section{IMPACT OF SPHERICAL FRIT BEADS ON SIMULATED DWPF SLURRIES (U)}

M. E. Smith

M. E. Stone

D. H. Miller

September 2005

Immobilization Technology Section Savannah River National Laboratory Aiken, SC 29808

Prepared for the U.S. Department of Energy Under Contract Number DEAC09-96SR18500

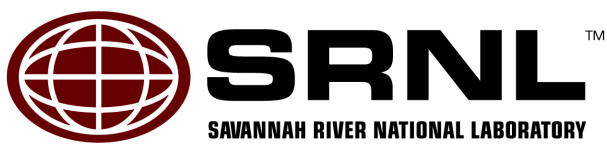

We Put Science To Work 


\section{REVIEWS AND APPROVALS}

\section{AUTHORS:}

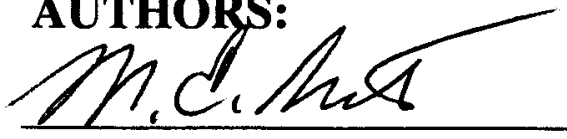

M. E. Smith, Immobilization Technology Section Mf fe

\section{TECHNICAL REVIEWERS:}

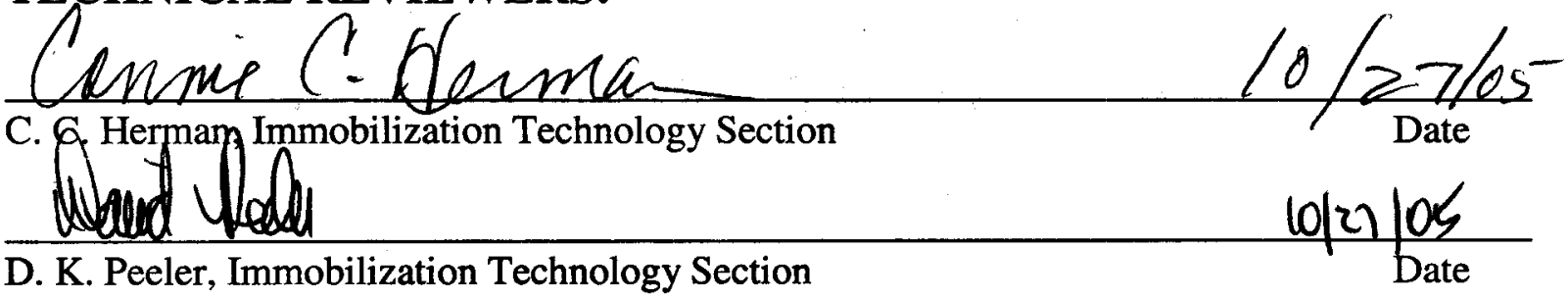

\section{APPROVERS:}

REEdu As $10 / 31105$

R. E. Edwards, Manager, Immobilization Technology Section Date Stance fMauc $10 / 31 / 05$

S. L. Marra, Manager, Glass Formulation \& Process Development Date
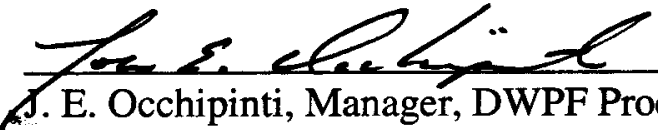


\section{EXECUTIVE SUMMARY}

It has been shown that the rheological properties of simulated Defense Waste Processing Facility (DWPF) melter feed with the glass former frit as mostly ( 90 weight percent) solid spherical particles (referred to as beads) were improved as the feed was less viscous as compared to DWPF melter feed that contained the normal irregular shaped frit particles. ${ }^{1}$ Because the physical design of the DWPF Slurry Mix Evaporator (SME), Melter Feed Tank (MFT), and melter feed loop are fixed, the impact of changing the rheology might be very beneficial. Most importantly, higher weight percent total solids feed might be processed by reducing the rheological properties (specifically yield stress) of the feed. Additionally, if there are processing problems, such as air entrainment or pumping, these problems might be alleviated by reducing the rheological properties, while maintaining targeted throughputs. Rheology modifiers are chemical, physical, or a combination of the two and can either thin or thicken the rheology of the targeted slurry. The beads are classified as a physical rheological modifier in this case.

Even though the improved rheological properties of the feed in the above mentioned DWPF tanks could be quite beneficial, it is the possibility of increased melt rate that is the main driver for the use of beaded glass formers. By improving the rheological properties of the feed, the weight percent solids of the feed could be increased. This higher weight percent solids (less water) feed could be processed faster by the melter as less energy would be required to evaporate the water, and more would be available for the actual melting of the waste and the frit. In addition, the use of beads to thin the feed could possibly allow for the use of a lower targeted acid stoichiometry in the feed preparation process (if in fact acid stoichiometry is being driven by feed rheology as opposed to feed chemistry). Previous work by the Savannah River National Laboratory (SRNL) with the lab-scale Slurry-Fed Melt Rate Furnace (SMRF) showed that melt rate was increased with feeds with either higher weight percent solids or lower acid stoichiometry. ${ }^{2}$ Past SRNL pilot scale melter tests have also shown the same increase in melt rate with higher weight percent solids. ${ }^{3}$

Although the use of beads may increase melt rate and also aid in the operation of the SME, MFT, and melter feed loop, there are several issues that must be addressed before going into a more in depth study of the use of beads at DWPF. The following issues were investigated and are documented in this report.

- The impact of glass former shape on settling behavior

- Impact of glass former shape on the rheology of the feed product

- Impact of glass former shape on erosion of equipment containing glass formers

- Impact of glass former shape on slurry addition to the SME

- Impact of glass former shape on melt rate

The tests did not show any problems with regards to the above process impacts investigated. Because the beads were shown to reduce the rheological properties of the SME product (or melter feed), a higher weight percent solids feed could be processed in the melter. From past pilot scale testing ${ }^{3}$ as well as limited DWPF operational experience, this could increase the DWPF melt rate by about 2-5 percent for every weight percent solids increase allowed by the use of beads as the glass former. 


\section{TABLE OF CONTENTS}

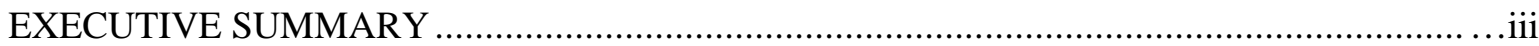

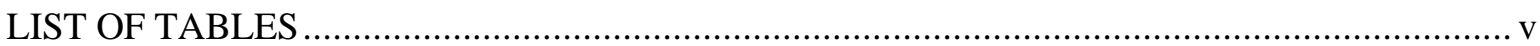

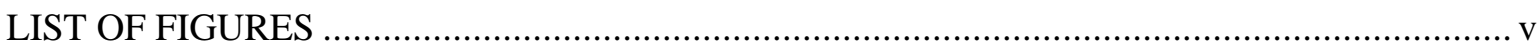

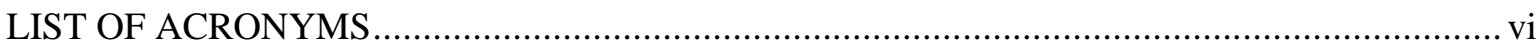

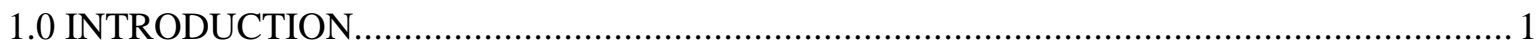

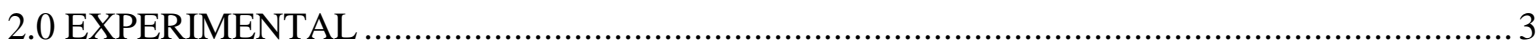

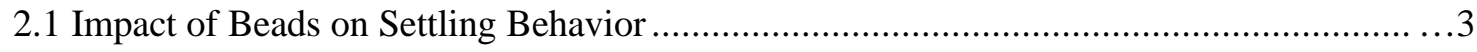

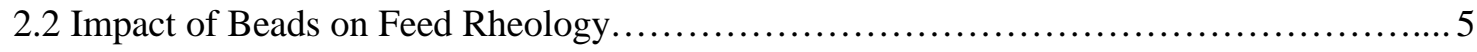

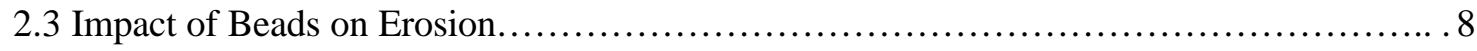

2.4 Impact of Beads on Slurry Additions to SME $\ldots \ldots \ldots \ldots \ldots \ldots \ldots \ldots \ldots \ldots \ldots \ldots \ldots \ldots \ldots \ldots$

2.5 Impact of Beads on Melt Rate..................................................

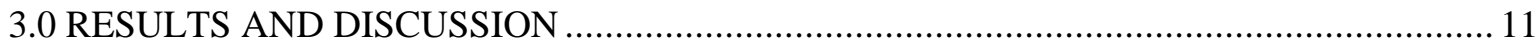

3.1 Impact of Beads on Settling Behavior ..........................................................................

3.1.1 Initial Settling Tests in Water and Xanthan Gum Slurry .......................................................11

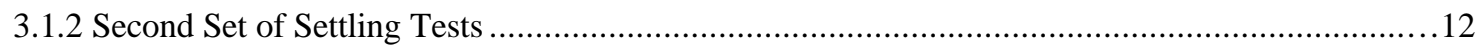

3.1.3 SRAT Product Settling Tests.............................................................................................13

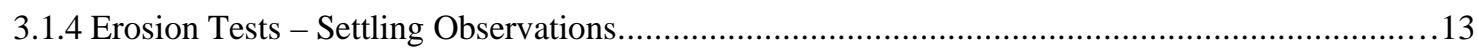

3.2 Impact of Beads on Feed Rheology.............................................. 14

3.3 Impact of Beads on Erosion....................................................... 16

3.4 Impact of Beads on Slurry Additions to SME......................................17

3.5 Impact of Beads on Melt Rate.................................................... 19

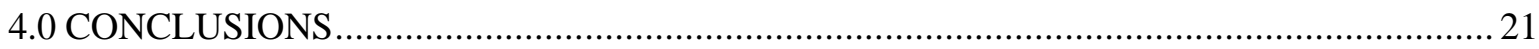

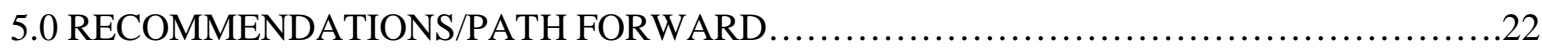

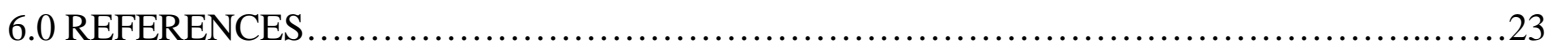

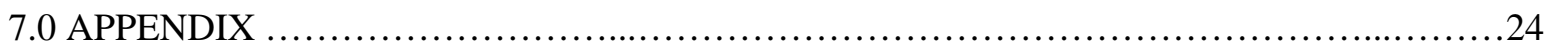




\section{LIST OF TABLES}

Table 2-1. Analysis of Frit 320 (Frit and After Made into Beads) .............................................

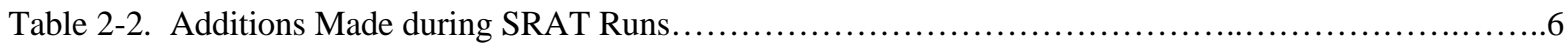

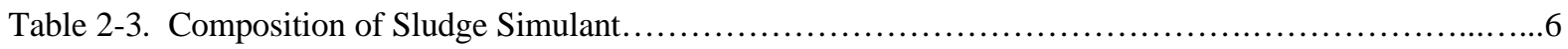

Table 2-4. SRAT Product Composition.........................................................................

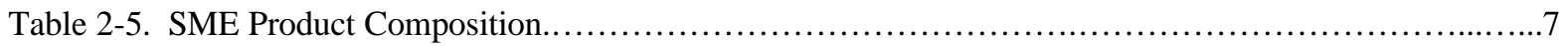

Table 3-1. First Frit 320/Beads Settling Test Results in Water.................................................................11

Table 3-2. First Frit 320/Beads Settling Test Results in Xanthan Gum Slurry ..............................11

Table 3-3. Frit 320(-80+100 mesh)/Beads (-70+100 mesh) Settling Test Results in Xanthan Gum Slurry.......12

Table 3-4. Frit 320(-100+140 mesh)/Beads (-100+140 mesh) Settling Test Results in Xanthan Gum Slurry....13

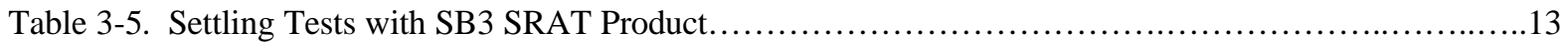

Table 3-6. Impact of Frit 320 and Various Sized Beads on Rheology of SB3 SME Product ..................15

Table 3-7. Rheological Results for SME Products.....................................................

Table 3-8. Impact of Beads Agitator Erosion Test......................................................... 17

Table 3-9. Summary of Bead/Frit Mixture Recircualtion Test............................................18

\section{LIST OF FIGURES}

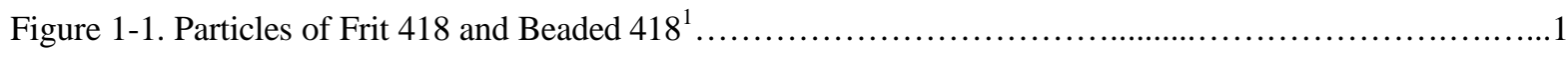

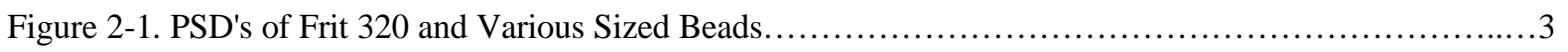

Figure 2-2. Settling Test Setup with Frit 320 and Various Sized Beads.................................... 4

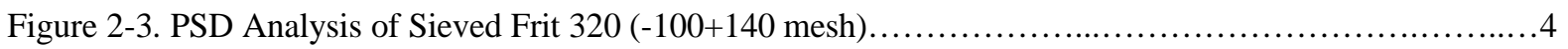

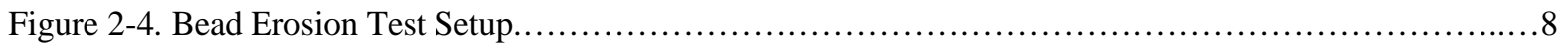

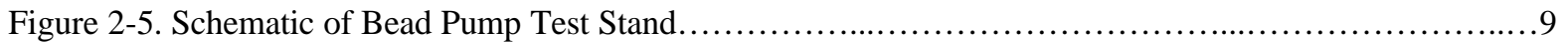

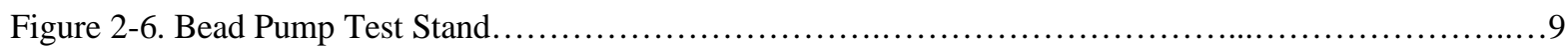

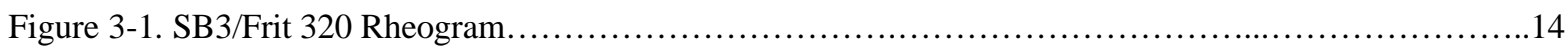

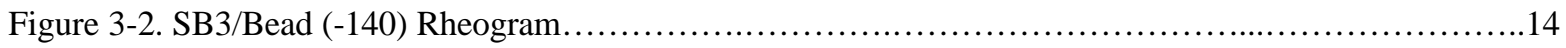

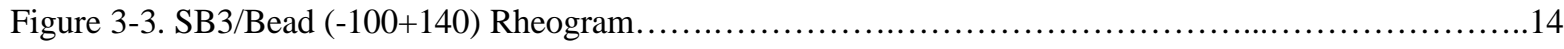

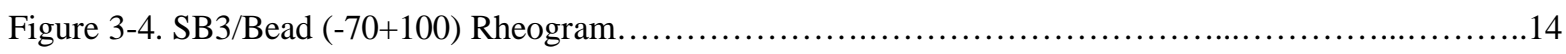

Figure 3-5. Flow Curves for 52 Weight \% Solids SME Bead and Frit 320 Products.............................16

Figure 3-6. Flow Curves for 45 Weight \% Solids SME Bead and Frit 320 Products............................16

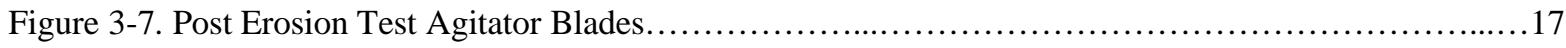

Figure 3-8.Impact of Flow on Line Pressure for Bead and Frit 320 Mixtures................................19

Figure 3-9.Top Views of the SB3/Bead 320 and SB3/Frit 320 MRF Beakers and the

Cross-Sections of the Beakers .20 


\section{LIST OF ACRONYMS}

$\begin{array}{ll}\text { ACTL } & \text { Aiken County Technology Laboratory } \\ \text { CEF } & \text { Cold Cap Evaluation Furnace } \\ \text { DWPF } & \text { Defense Waste Processing Facility } \\ \text { FSMT } & \text { Frit Slurry Makeup Tank } \\ \text { LMR } & \text { Linear Melt Rate } \\ \text { MFT } & \text { Melter Feed Tank } \\ \text { MRF } & \text { Melt Rate Furnace } \\ \text { MWWT } & \text { Mercury Water Wash Tank } \\ \text { PSD } & \text { Particle Size Distribution } \\ \text { SB3 } & \text { Sludge Batch 3 } \\ \text { SOA } & \text { Source of Alkali } \\ \text { SME } & \text { Slurry Mix Evaporator } \\ \text { SMRF } & \text { Slurry-Fed Melt Rate Furnace } \\ \text { SRAT } & \text { Sludge Receipt Adjustment Tank } \\ \text { SRNL } & \text { Savannah River National Laboratory } \\ \text { TTR } & \text { Technical Task Request }\end{array}$




\subsection{INTRODUCTION}

It has been shown that the rheological properties of simulated Defense Waste Processing Facility (DWPF) melter feed with the glass former frit as mostly (90 weight percent) solid spherical particles (referred to as beads) were improved as the feed was less viscous as compared to DWPF melter feed that contained the normal irregular shaped frit particles. ${ }^{1}$ Figure 1-1 shows typical DWPF frit particles (left picture) and the same material after being turned into beads (right picture - two particles not beaded are in picture).
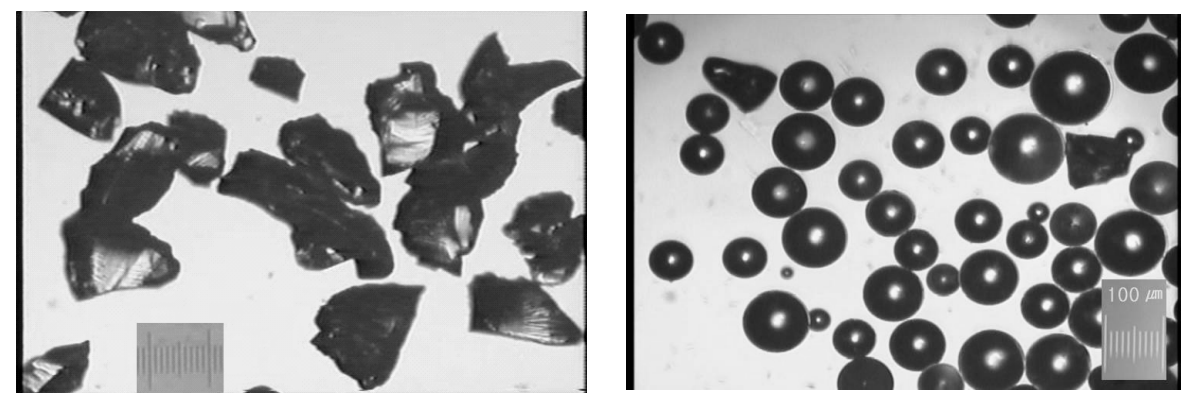

Figure 1-1. Particles of Frit 418 and Beaded $418^{1}$

The melter feed is a non-Newtonian fluid whose behavior is evaluated using the Bingham Plastic model to determine the yield stress and consistency of the feed. The yield stress is the dominant parameter for controlling the behavior of the process in the shear rate typical of the DWPF process equipment. If the yield stress is too low, the glass former (currently glass frit) may settle and cause inhomogeneity in the feed. The upper limit is set by the capabilities of the DWPF processing equipment. During SB2, issues with highly viscous feed were noted which led to air entrainment during mixing and loss of pump prime during transfers. It was also suspected that this thick feed did not flow well on top of the DWPF Melter glass pool, thereby negatively impacting the rate the melter could melt the feed.

The yield stress is affected by many parameters, but lowering the solids content or increasing the amount of acid added during sludge pretreatment are the two adjustments currently utilized at DWPF to reduce the yield stress of highly viscous feeds.

Because the physical design of the DWPF Sludge Receipt Adjustment Tank (SRAT), Slurry Mix Evaporator (SME), Melter Feed Tank (MFT), and melter feed loop are fixed, the impact of changing the rheology might be very beneficial. Most importantly, higher weight percent total solids feed might be processed by reducing the rheological properties (namely yield stress) of the feed. Additionally, if there are processing problems, such as air entrainment or pumping, these problems might be alleviated by reducing the rheological properties, while maintaining targeted throughputs. Rheology modifiers are chemical, physical, or a combination of the two and can either thin or thicken the rheology of the targeted slurry. The beads are classified as a physical rheological modifier in this case.

Even though the improved rheological properties of the feed in the above mentioned DWPF tanks could be quite beneficial, it is the possibility of increased melt rate that is the main driver for the use of beaded glass formers. By improving the rheological properties of the feed, the weight percent solids of the feed could be increased. This higher weight percent solids (less water) feed could be processed faster by the melter as less energy would be required to evaporate the water, and more would be available for the actual melting of the waste and the frit. In addition, the use of beads to thin the feed could possibly allow for the use of a lower targeted acid stoichiometry in the feed preparation process (if in fact acid stoichiometry is being driven by feed rheology as opposed to feed chemistry). Previous work by the Savannah River National Laboratory (SRNL) with the lab-scale Slurry-Fed Melt Rate Furnace (SMRF) showed that melt rate was increased with feeds with either higher weight percent solids or lower acid 
stoichiometry. ${ }^{2}$ In addition, past SRNL pilot scale melter tests have also shown the same increase in melt rate with higher weight percent solids. ${ }^{3}$

Although the use of beads may increase melt rate and also aid in the operation of the SRAT, SME, MFT, and melter feed loop, there are several issues that must be addressed before going into a more in depth study of the use of beads at DWPF. The following issues were investigated and are documented in this report.

- The impact of glass former shape on settling behavior - The beads have the potential to settle faster than the frit in the DWPF process tanks. ${ }^{4,5}$

- The results of the settling behavior tests were used to select a bead size for the other issues investigated below.

- Impact of glass former shape on the rheology of the feed product - Sludge Receipt Adjustment Tank (SRAT) product Sludge Batch 3 (SB3) was mixed with the various sized glass beads or Frit 320 to determine the impact of beads on SME product rheology. In addition, SRAT/SME cycles were performed using beaded Frit 320 and standard Frit 320. Rheology measurements were performed on the products from both tests.

- Impact of glass former shape on erosion - Using beaded frit versus the irregularly shaped frit currently used could help reduce the erosion rates of agitators, impellers, and the piping systems now used in mixing or transporting slurries containing the glass former.

- Impact of glass former shape on frit slurry addition to the SME - Due to the potential for the beads to settle faster than frit, mixing studies were performed with water slurries at different weight percent solids of frit or beads to determine the agitator speeds required to maintain frit and bead suspension. The minimum transport velocities (velocity at which particles just begin to deposit) were also determined for each slurry.

- Impact of glass former shape on melt rate - Feed from the above mentioned SRAT/SME runs were tested in the dry-fed Melt Rate Furnace (MRF) to determine if beads had a impact on melt rate. More specifically, do beads negatively impact melt rate, thereby possibly negating gains that could be achieved by processing feed with a higher weight percent solids in the DWPF Melter via the use of beaded frit. Beaded Frit 320 and standard Frit 320 were tested.

This task was initiated by DWPF Engineering via Task Technical Request (TTR) HLW-DWPF-20050005 to the SRNL. The work was performed per Task Technical and Quality Assurance Plan WSRCRP-2005-01399. All work documented in this report is recorded in laboratory notebook WSRC-NB2005-00017 (except for the melt rate study that is recorded in WSRC-NB-2003-00213). All work was performed at the Aiken County Technology Laboratory (ACTL). 


\subsection{EXPERIMENTAL}

\subsection{Impact of Beads on Settling Behavior}

Settling behavior tests were performed per three run plans. The first set of tests was performed per SRNL-ITS- 2005-00165 (Run Plan for "Impact of Glass Former Shape on Settling Behavior" Tests). Relative settling rates of as received Frit 320 (lot 320L22, Bin 5/KJ40355) and Potter Industry Inc. P series beads sized at -140 mesh (lot 2L3971-3), -100+140 mesh (lot 2L3971-2), and -70+100 mesh (lot 2L3971-1) were tested in both water and a Xanthan gum slurry that targeted a Bingham Plastic fluid having a yield stress of 2.5 Pascals (lower limit for the SME). As received Frit 320 has a mesh size of $80+200$ mesh. $1000 \mathrm{ml}$ of the Xanthan gum slurry was made by mixing 0.25 weight percent Xanthan gum powder (lot 2502799), 0.199 weight percent Kathon CG/ICP preservative (0004999303 stamped on container), and 99.551 weight percent water. The Xanthan gum slurry was stirred until it was homogeneous, then a sample was taken to check the yield stress. The analysis showed that the slurry had a yield stress of 2.2 Pascals. Samples of the various glass formers were taken and submitted for Particle Size Distribution (PSD) analyses which were run after these tests. The PSD results were deemed acceptable for all of the glass formers (see Figure 2-1). The water settling test was done to simulate conditions in the DWPF Frit Slurry Makeup Tank (FSMT). The same Xanthan gum slurry, as well as the same beads and Frit 320 were used for all of the tests in this report unless noted otherwise.

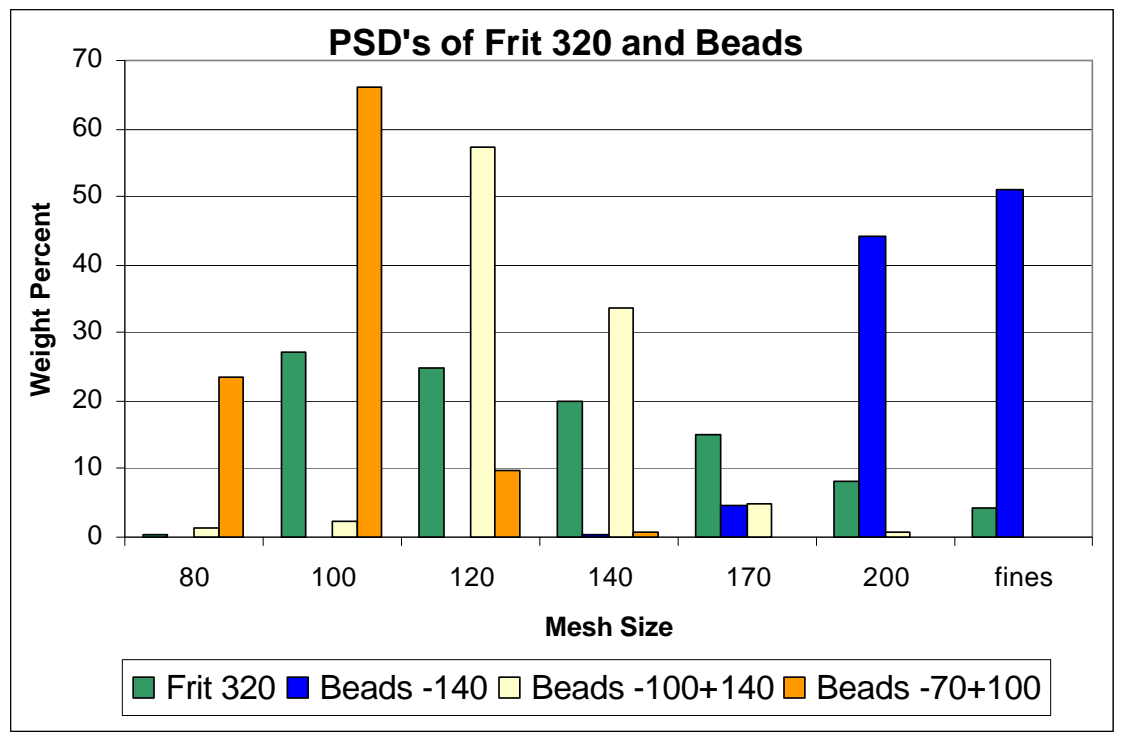

Figure 2-1. PSD's of Frit 320 and Various Sized Beads

To perform the water settling tests, four $100 \mathrm{ml}$ graduated cylinders were filled with water and then each had five grams of one of the different sized beads or Frit 320 added to it. The addition of the glass formers was done by two people so that all of the glass formers tested could be added at the same time. The first time this was done, the cylinders were not shaken. A repeat of this test was done by first adding the glass formers, and then covering and shaking the cylinders. Settling times for each glass former were then determined via a stop watch.

The same steps were used for the Xanthan gum slurry tests. As noted above, the cylinders were covered and shaken before timing began. Unlike the water tests that had settling times in minutes, the Xanthan gum slurry tests lasted about 24 hours. Both the water and Xanthan gum tests were videotaped. These tests were run on 7/12/05 and 7/13/05. Figure 2-2 shows the test setup. The cylinders marked A, B, C, and D contain Frit 320, -140 mesh beads, -100+140 mesh beads, and -70+100 mesh beads respectively. 


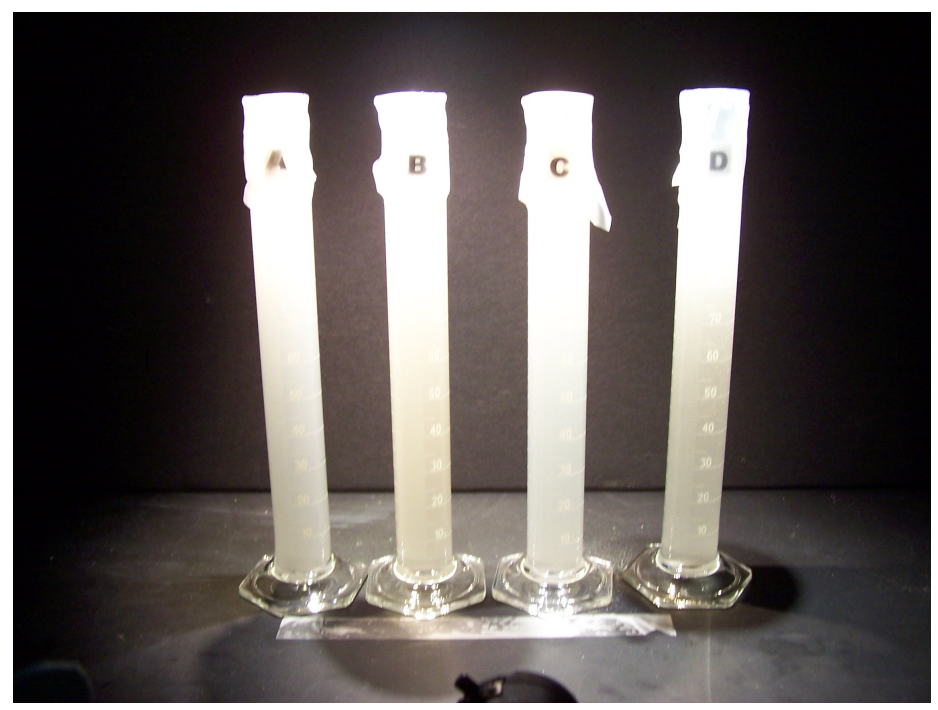

Figure 2-2. Settling Test Setup with Frit 320 and Various Sized Beads

The second set of settling tests was performed per SRNL-ITS-2005-00170 (Run Plan for "Impact of Glass Former Shape on Settling Behavior" Test). These tests were run the same as the first set of settling tests, but this time sieved Frit $320(-100+140$ mesh) and beads $(-100+140$ mesh) were tested in water and the Xanthan gum slurry. These tests were run on 7/19/05 and 7/20/05. A PSD analysis was run on a sample of the sieved Frit $320(-100+140$ mesh) and is shown below in Figure 2-3. The PSD was acceptable, although almost 25 percent of the weight was frit that went through the 140 mesh screen. This would cause the settling of the sieved Frit 320 to be less than what would be expected.

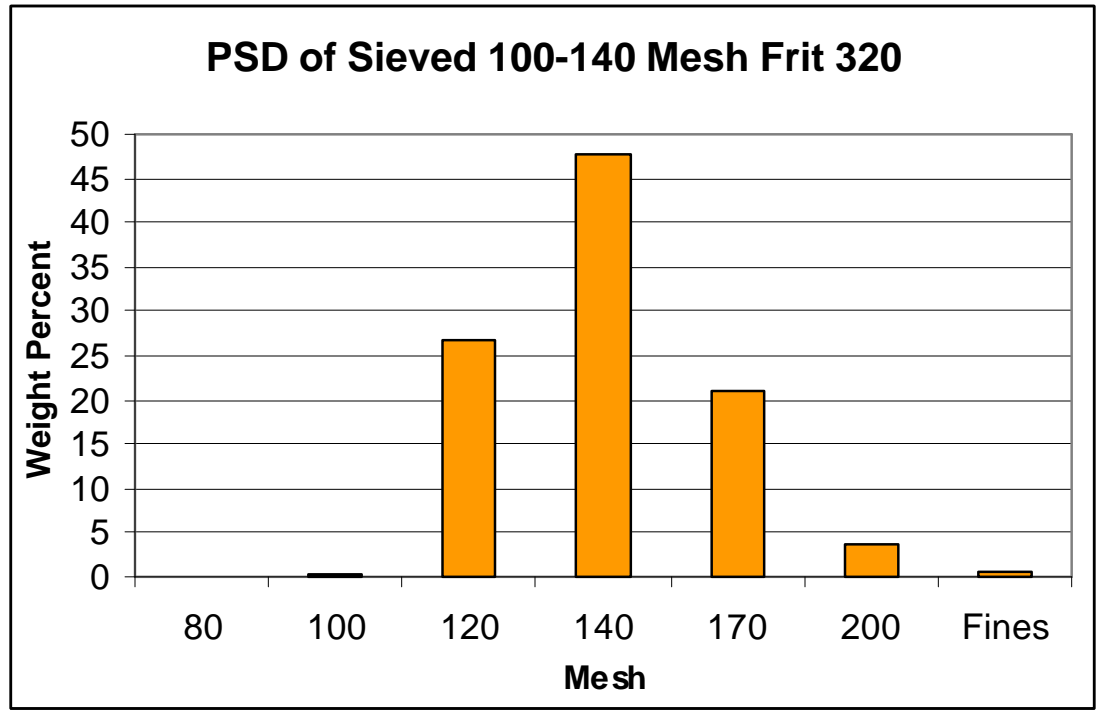

Figure 2-3. PSD Analysis of Sieved Frit 320 (-100+140 mesh)

The final settling tests were performed per SRNL-ITS-2005-0000181 (Run Plan for "Impact of Glass Former Shape/Size on Settling Behavior Confirmatory Settling Tests). In these tests, settling tests were made in $100 \mathrm{ml}$ graduated cylinders using SB3 SRAT product (FPMR-0134A - made in March 2005) mixed with sieved Frit $320(-100+140$ mesh) or $-100+140$ mesh beads. The purpose of these tests was to determine the relative settling rates of the different shaped glass formers in a SME product. The glass 
formers were added in amounts to give a $100 \mathrm{ml}$ slurry at $40 \%$ waste loading. Appendix A gives the data from the analysis of the SRAT product.

The SRAT product and glass formers were mixed thoroughly before pouring into the $100 \mathrm{ml}$ graduated cylinders. Five $\mathrm{ml}$ pipet samples were taken at the $50 \mathrm{ml}$ level in each cylinder 2, 4, 6, and 24 hours after pouring the slurries into the cylinders. Care was taken to prevent any slurry from getting into the pipet until the tip of the pipet was at the $50 \mathrm{ml}$ level. These samples were submitted for weight percent solids analyses. These analyses were used to determine settling differences as visual settling determinations could not be done in the dark brown SME product.

\subsection{Impact of Beads on Feed Rheology}

Two separate tests were run to determine the impact of beads on SME (or melter feed) rheology. The first test was performed per SRNL-ITS-2005-00182 (Run Plan for Impact of Glass Former Shape on SME Product Rheology). In this test, $110 \mathrm{ml}$ slurries of SB3 SRAT product FPMR-0134A (same SRAT product used in settling behavior tests discussed in Section 2.1) and either Frit 320 (as received) or glass beads (-140 mesh, $-100+140$ mesh, or $-70+100$ mesh) were made. 118.34 grams of the SRAT product was added and 32.48 grams of the glass former. The targeted waste loading and weight percent solids were $40 \%$ and $45 \%$ respectively. All four resultant SME products were submitted for rheograms.

The second evaluation of the impact of beads on SME product rheology test was done after completion of a SME cycle using the beads in place of frit. Two SRAT/SME cycles were run per SRNL-ITS-200500192. Details of the two SRAT/SME runs are given below. Additional details (including off-gas generation details) of the two SRAT/SME runs are included in Appendix B for information only. Both runs utilized the same starting sludge and acid addition amounts. The first run utilized Frit 320 as received from DWPF while the second run utilized Frit 320 that had been processed into spheres and then sized to $-100+200$ mesh. SB3 baseline sludge simulant was used for the testing. The Bead 320 was made by making Frit 320 into spheres using the Flame Former system at ACTL. The Frit 320 used was from DWPF lot number 320L22. There was some concern that the heat treatment may impact the chemical composition of the frit, so analyses of the Frit 320 and the beads were made. The results are given in Table 2-1. No change in composition occurred as a result of the beading process.

Table 2-1. Analysis of Frit 320 (Frit and After Made into Beads)

\begin{tabular}{|c|c|c|c|c|c|c|c|c|c|}
\hline Sample & Lab ID & $\mathrm{Al}_{2} \mathrm{O}_{3}$ & $\mathrm{~B}_{2} \mathrm{O}_{3}$ & $\mathrm{CaO}$ & $\mathrm{Fe}_{2} \mathrm{O}_{3}$ & $\mathrm{Li}_{2} \mathrm{O}$ & $\mathrm{Na}_{2} \mathrm{O}$ & $\mathrm{SiO}_{2}$ & $\mathrm{TiO}_{2}$ \\
\hline Frit 320 & $05-0565$ & 0.958 & 7.18 & 0.055 & 0.078 & 7.18 & 11.9 & 71.3 & 0.048 \\
\hline Bead $320<120 \mu \mathrm{m}$ & $05-0566$ & 0.992 & 7.08 & 0.052 & 0.081 & 7.34 & 11.8 & 70.7 & 0.048 \\
\hline Bead $320>120 \mu \mathrm{m}$ & $05-0567$ & 0.993 & 7.13 & 0.040 & 0.063 & 7.34 & 12.0 & 70.2 & 0.043 \\
\hline
\end{tabular}

Two 4L SRAT/SME vessels were setup. The complete apparatus includes two condensers $\left(40^{\circ} \mathrm{C}\right.$ and $10^{\circ} \mathrm{C}$ ), Mercury Water Wash Tank (MWWT), an antifoam funnel, air purge, $\mathrm{pH}$ probe, temperature controller, heating mantle, manometer, acid addition pumps, gas chromatograph, and a mixer. Once the apparatus was assembled and checked for leaks, sludge simulant was added to each vessel and trimmed as shown in Table 2-2. Mercury was not added during the runs to avoid emissions during melt rate testing (the SME products were tested in the MRF as part of the Impact of Beads on Melt Rate testing as discussed in Sections 2.5 and 3.5 of this report). The vessels were then heated to $93^{\circ} \mathrm{C}$, and the nitric and formic acid additions were performed with the MWWT's in reflux mode. IIT-747 antifoam was added to control foaming during the heatup and again after all acid additions were completed. The vessel contents were brought to a boil and condensate was collected in a bottle until the dewater target was reached. The MWWT's were then switched to reflux and the vessel contents were boiled for 12 hours. 
WSRC-TR-2005-00418

Table 2-2. Additions during SRAT Runs

\begin{tabular}{|c|c|c|}
\hline Fresh Sludge without trim chemicals & 2800 & gms \\
\hline Coal & 0.44 & gms \\
\hline Sand $\left(\mathrm{SiO}_{2}\right)$ & 1.88 & gms \\
\hline $\mathrm{AgNO}_{3}$ & 0.11410 & gms \\
\hline $\mathrm{Pd}\left(\mathrm{NO}_{3}\right)_{2}{ }^{*} \mathrm{H}_{2} \mathrm{O}$ & 0.058 & gms of slurry \\
\hline $\mathrm{Rh}\left(\mathrm{NO}_{3}\right)_{3} * 2 \mathrm{H}_{2} \mathrm{O}$ & 0.971 & gms of slurry \\
\hline $\mathrm{RuCl}_{3}$ & 0.543 & gms solid \\
\hline Rinse water & 50.00 & gms \\
\hline
\end{tabular}

At the completion of the 12 hour reflux, two $30 \mathrm{ml}$ samples were pulled from each vessel after the vessels had cooled. Frit or beads, water, and formic acid were then added to the vessel and the vessel contents were reheated to boiling. The frit and beads were added to target a waste loading of $35 \%$. After dewatering an amount equal to the water and formic acid additions, the vessels were allowed to cool. A second frit or bead addition and dewater was performed, followed by a third addition. After the third frit (or bead) addition, the vessels were dewatered until the run with beads began to experience mixing difficulties. Samples were then pulled of each SME product.

The sludge simulant used during the testing was designated FPMR-0136. The composition of this simulant prior to trim chemical addition is shown in Table 2-3. Analysis of the trimmed sludge was not performed as the trim additions are minor components and do not significantly impact overall composition. This sludge composition is the baseline SB3 sludge simulant. The two SRAT product samples were analyzed and results are shown in Table 2-4. The results indicate that both SRAT products have the same composition to within 5\% for significant components. The two SME product samples were analyzed and results are shown in Table 2-5. The elemental weight percents given in Tables 2-3, 24, and 2-5 are all given on a calcined solids basis. The results indicate that both SME products have the same composition to within $5 \%$ for significant components. The waste loading calculated from the lithium content was within $6 \%$ of the target (35\%) and was the same for both batches of SME product.

Table 2-3. Composition of Sludge Simulant

\begin{tabular}{|c|c|c|c|}
\hline Element & Calcined Wt \% & Anions & $\mathrm{mg} / \mathrm{kg}$ \\
\hline $\mathrm{Al}$ & 9.11 & Nitrite & 18900 \\
\hline $\mathrm{Ba}$ & 0.1255 & Nitrate & 13700 \\
\hline $\mathrm{Ca}$ & 2.22 & Sulfate & 2085 \\
\hline $\mathrm{Cr}$ & 0.152 & & \\
\hline $\mathrm{Cu}$ & 0.1365 & Solids Content & Weight $\%$ \\
\hline $\mathrm{Fe}$ & 27.4 & & \\
\hline $\mathrm{Gd}$ & 0.068 & Total Solids & 11.34 \\
\hline $\mathrm{K}$ & 0.122 & Insoluble Solids & 7.72 \\
\hline $\mathrm{Mg}$ & 2.705 & Soluble Solids & 3.62 \\
\hline $\mathrm{Mn}$ & 3.855 & Calcine Solids & 8.25 \\
\hline $\mathrm{Na}$ & 14.95 & & \\
\hline $\mathrm{Ni}$ & 0.9855 & Density $(\mathrm{g} / \mathrm{ml})$ & 1.16 \\
\hline $\mathrm{P}$ & 0.0455 & $\mathrm{pH}$ & 12.9 \\
\hline$S$ & 0.393 & & \\
\hline $\mathrm{Si}$ & 1.035 & & \\
\hline $\mathrm{Ti}$ & 0.021 & & \\
\hline $\mathrm{Zn}$ & 0.3225 & & \\
\hline $\mathrm{Zr}$ & 0.3975 & & \\
\hline
\end{tabular}


Table 2-4. SRAT Product Composition

\begin{tabular}{|c|c|c|c|c|c|}
\hline Element & Bead Run & Frit Run & Anions & Bead Run & Frit Run \\
\hline & \multicolumn{2}{|c|}{ Calcined Weight \% } & & \multicolumn{2}{|c|}{$\mathrm{mg} / \mathrm{kg}$} \\
\hline $\mathrm{Al}$ & 9.06 & 8.775 & Nitrite & $<100$ & $<100$ \\
\hline $\mathrm{B}$ & $<0.1$ & $<0.1$ & Nitrate & 31550 & 32500 \\
\hline $\mathrm{Ba}$ & 0.1335 & 0.13 & Sulfate & 1705 & 1710 \\
\hline $\mathrm{Ca}$ & 2.245 & 2.395 & Phosphate & $<100$ & $<100$ \\
\hline $\mathrm{Cr}$ & 0.167 & 0.172 & Oxalate & $<100$ & $<100$ \\
\hline $\mathrm{Cu}$ & 0.1355 & 0.1405 & Formate & 60500 & 61800 \\
\hline $\mathrm{Fe}$ & 29.7 & 29.05 & Chloride & $<100$ & $<100$ \\
\hline $\mathrm{Gd}$ & 0.071 & 0.071 & & & \\
\hline $\mathrm{K}$ & 0.1225 & 0.1175 & & Bead Run & Frit Run \\
\hline $\mathrm{Li}$ & $<0.1$ & $<0.1$ & & \multicolumn{2}{|c|}{ Weight $\%$} \\
\hline $\mathrm{Mg}$ & 2.81 & 2.9 & Total Solids & 26.74 & 27.04 \\
\hline $\mathrm{Mn}$ & 3.72 & 3.82 & Insoluble Solids & NM & NM \\
\hline $\mathrm{Na}$ & 15.6 & 15.85 & Soluble Solids & NM & NM \\
\hline $\mathrm{Ni}$ & 1.01 & 1.015 & Calcine Solids & 17.12 & 17.18 \\
\hline $\mathrm{P}$ & 0.032 & 0.044 & & & \\
\hline $\mathrm{Pb}$ & $<0.01$ & $<0.01$ & Density $(\mathrm{g} / \mathrm{ml})$ & 1.18 & 1.17 \\
\hline $\mathrm{S}$ & 0.4455 & 0.4295 & & & \\
\hline $\mathrm{Si}$ & 1.04 & 1.165 & & & \\
\hline $\mathrm{Zn}$ & 0.371 & 0.3375 & & & \\
\hline $\mathrm{Zr}$ & 0.3425 & 0.3855 & & & \\
\hline
\end{tabular}

Table 2-5. SME Product Composition

\begin{tabular}{|c|c|c|c|c|c|}
\hline Element & Bead Run & Frit Run & Anions & Bead Run & Frit Run \\
\hline & \multicolumn{2}{|c|}{ Calcined Weight \% } & & \multicolumn{2}{|c|}{$\mathrm{mg} / \mathrm{kg}$} \\
\hline $\mathrm{Al}$ & 3.505 & 3.49 & Nitrite & $<100$ & $<100$ \\
\hline $\mathrm{B}$ & 1.435 & 1.49 & Nitrate & 27050 & 28000 \\
\hline $\mathrm{Ba}$ & 0.064 & 0.064 & Sulfate & 1520 & 1965 \\
\hline $\mathrm{Ca}$ & 0.7425 & 0.732 & Phosphate & $<100$ & $<100$ \\
\hline $\mathrm{Cr}$ & 0.0685 & 0.065 & Oxalate & $<100$ & $<100$ \\
\hline $\mathrm{Cu}$ & 0.0515 & 0.063 & Formate & 55750 & 56800 \\
\hline $\mathrm{Fe}$ & 9.8 & 9.865 & Chloride & $<100$ & $<100$ \\
\hline $\mathrm{Gd}$ & 0.0275 & 0.029 & & & \\
\hline $\mathrm{K}$ & 0.0845 & 0.077 & & Bead Run & Frit Run \\
\hline $\mathrm{Li}$ & 2.335 & 2.345 & & \multicolumn{2}{|c|}{ Weight $\%$} \\
\hline $\mathrm{Mg}$ & 1.025 & 1.017 & Total Solids & 51.08 & 51.88 \\
\hline $\mathrm{Mn}$ & 1.3 & 1.305 & Insoluble Solids & 39.30 & 39.78 \\
\hline $\mathrm{Na}$ & 11.1 & 11.55 & Soluble Solids & 11.79 & 12.10 \\
\hline $\mathrm{Ni}$ & 0.3615 & 0.3605 & Calcine Solids & 42.38 & 43.01 \\
\hline $\mathrm{P}$ & 0.0415 & 0.0345 & & & \\
\hline $\mathrm{Pb}$ & 0.0405 & 0.039 & Density $(\mathrm{g} / \mathrm{ml})$ & 1.48 & 1.47 \\
\hline $\mathrm{S}$ & 0.1455 & 0.139 & $\mathrm{pH}$ & 7.46 & 7.41 \\
\hline $\mathrm{Si}$ & 22.6 & 22.55 & & & \\
\hline $\mathrm{Zn}$ & 0.218 & 0.15 & Waste Loading* & 37.25 & 36.98 \\
\hline $\mathrm{Zr}$ & 0.2165 & 0.2035 & & & \\
\hline
\end{tabular}

* Waste loading calculated from $\mathrm{Li}_{2} \mathrm{O}$ concentration in SME product. 


\subsection{Impact of Beads on Erosion}

The erosion impact test was performed per run plan SRNL-ITS-2005-00204 (Run Plan for "Impact of Glass Beads on Agitator Erosion"). Three liter glass cylinder vessels were filled with 2 liter slurries (50 weight percent solids) of water and either Frit 320 or beads $(-100+140$ mesh). The steel agitator blades used in each vessel were cleaned, dried, and then weighed before the test was begun. Two glass baffles were placed in each vessel to increase the rate of erosion on the agitator blades. An agitator speed of 350 rpm was used for the entire test as this was about the slowest agitator speed that prevented settling of both glass formers tested. A tachometer was utilized to verify the agitator speed before the test was started and at the end of the test. The test was started on 8/25/05 and was run continuously for 14 days. At the completion of the test, the agitator blades were removed, cleaned, dried, and then reweighed to determine the weight loss and hence the amount of erosion caused by the beads or the Frit 320 . Figure 2-4 shows the test setup. Before the test was started, the relative settling behavior for the frit and beads were also determined by lowering the agitator speed for each vessel until a layer of water was observed at the top of the glass former/water mixture. This was easy to do with the clear glass vessels used in this test. The results of this settling test will be discussed in Section 3.1 of the report (Settling Behavior).

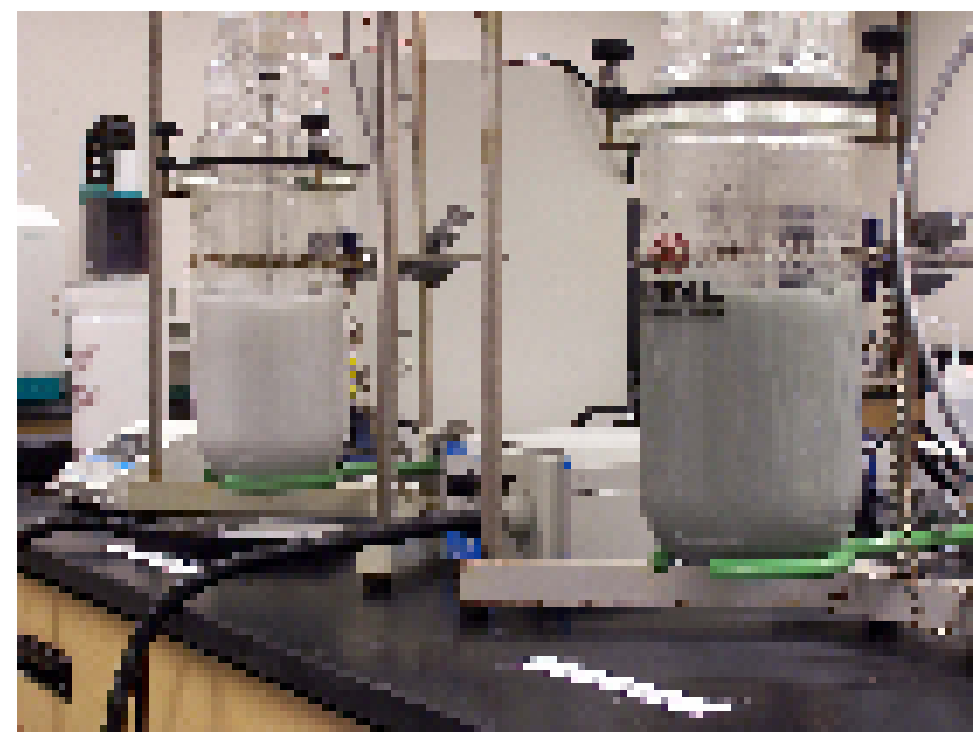

Figure 2-4. Bead Erosion Test Setup

\subsection{Impact of Beads on Slurry Addition to SME}

The slurry addition to the SME impact tests were performed per run plan SRNL-ITS-2005-00212 (Run Plan for "Bead/Frit Mixing and Transport Tests"). A recirculation loop made of clear 3/4" PVC piping was built with a total length of about 30 feet. The test rig had a plastic 10 gallon feed tank and a Jabsco pump. A 2" PVC bypass return loop to the feed tank was installed immediately after the pump with a ball valve to control flow in the main recirculation loop. A flow transmitter followed by both a pressure gauge and a digital pressure gauge were installed on the outlet side of the pump. A schematic of the bead pump test stand and a picture of the test stand (without the bypass line) are shown in Figures 2-5 and 2-6 respectively. Six gallon slurries of water and either $-100+140$ mesh beads or Frit 320 were tested. In the first test, $14 \mathrm{~kg}$ of water was first added to the feed tank, and then $14.0 \mathrm{~kg}$ of beads (to make a 50 weight percent solids slurry) was slowly added with the agitator running. A minimum agitator speed was then determined that prevented bead settling. After this, the pump was started with the bypass valve closed for maximum recirculation flow. Pump power, flow rate, outlet pressure, and observations of the flow in the horizontal upper section of the loop were noted. The recirculation flow was then gradually reduced and the above items recorded until settling was noted in the recirculation 
line. After this, the test was repeated by adding $3.11 \mathrm{~kg}$ of beads to make a 55 weight percent mixture. Finally, a 60 weight percent mixture was tested by adding another $3.89 \mathrm{~kg}$ of beads to the feed tank. This same process was planned for Frit 320, but only the initial 50 weight percent mixture could be tested before the nitrile pump impeller failed due to the erosive Frit 320 particles.

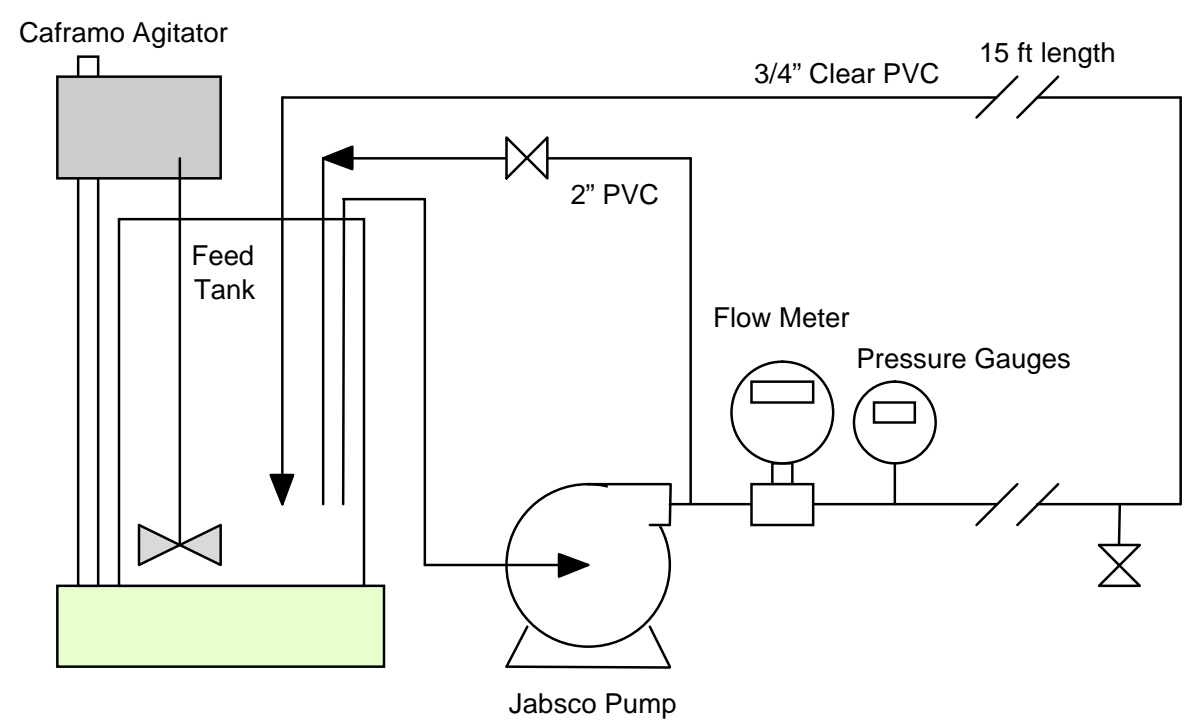

Figure 2-5. Schematic of Bead Pump Test Stand

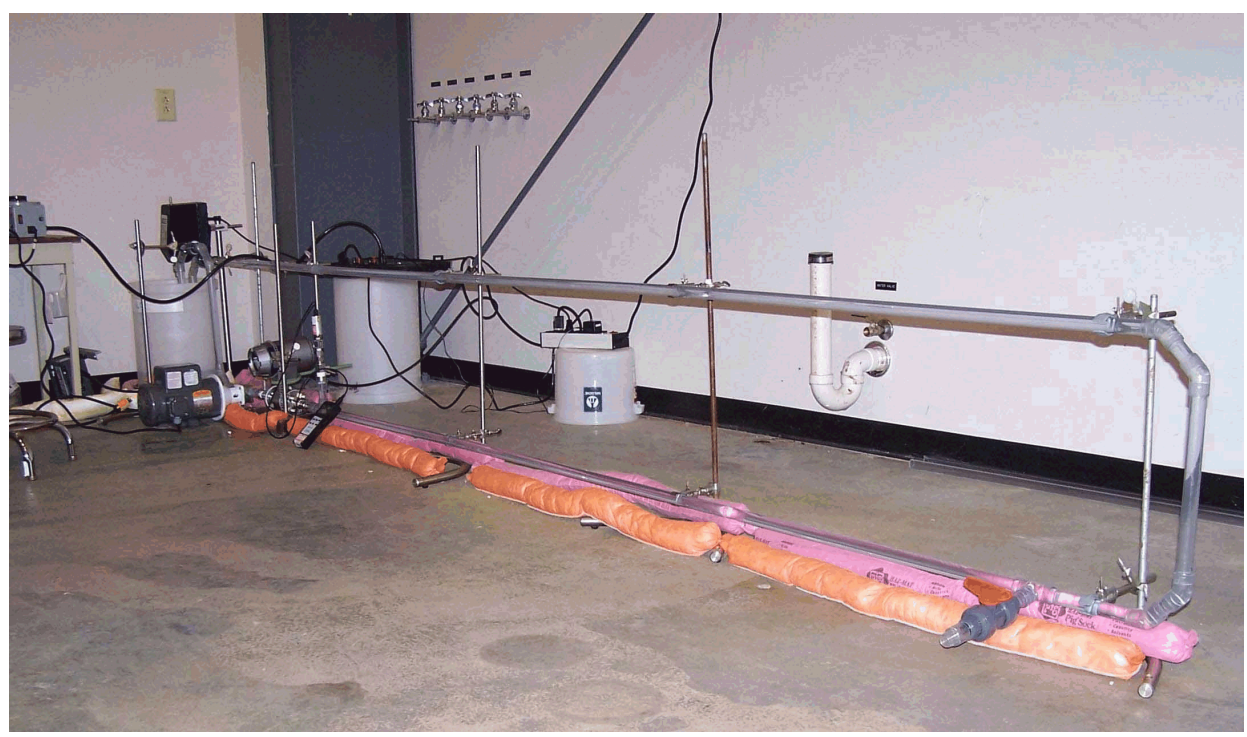

Figure 2-6. Bead Pump Test Stand

\subsection{Impact of Beads on Melt Rate}

Feed from the two SRAT/SME runs described in Section 2.2 of this report was used to determine the impact of beads on melt rate. As discussed before, the two SME products were SB3 with either as received Frit $320(-80+200$ mesh) or Bead $320(-100+200$ mesh) at a targeted waste loading of 35\%. The feeds were dried and then melted in the dry-fed MRF per SRNL-ITS-2005-00200 (Run Plan for Bead 
Test with SB3 and Bead 320 at 35\% Waste Loading) or SRNL-ITS-2005-00201 (Run Plan for Bead Test with SB3 and Frit 320 at 35\% Waste Loading).

The dry-fed MRF has a cylindrical inner chamber that is approximately 0.5 cubic feet in size, with heating coils winding around the chamber walls. The diameter of the chamber is $\sim 7$ ", and an insulating sleeve and a $1200 \mathrm{ml}$ stainless steel beaker (6" deep) were inserted from the top. The tests were conducted with the stainless steel beakers inserted with the sleeve so that the beaker bottom was approximately flush with the top of the uppermost chamber coil. An insulating block was used to cover the beaker. The furnace was heated to $1150^{\circ} \mathrm{C}$ with the top opening covered. Once the furnace reached the set point, the cover was removed and the beaker containing sufficient dried, sieved material to produce 525 grams of glass was inserted. After 50 minutes, the beaker was removed from the furnace and allowed to cool to room temperature.

This residence time in the furnace was determined during testing in 2002 to establish a standard test time for melt rate comparison for this dry-fed furnace. ${ }^{6}$ After cooling down, the beakers are then sectioned. The relative melt rate is determined by measuring the height of the glass layer in the bottom of each sectioned beaker at 0.25 " intervals. The average height and duration in the furnace is used to yield a relative linear melt rate number (inches/hour). General observations of the sectioned beaker are also used to describe differences between runs. 


\subsection{RESULTS AND DISCUSSION}

\subsection{Impact of Beads on Settling Behavior}

As discussed in Section 2.1, a series of settling tests with Frit 320 and beads were performed. These tests were performed to address glass former settling concerns with frit slurry (water) or the SME/MFT contents (used either Xanthan gum slurry or SB3 SRAT product). The results of the test will be given in the order in which they were performed. Any PSD's of the glass formers tested are reported in Section 2.1.

\subsubsection{Initial Settling Tests in Water and Xanthan Gum Slurry}

The first settling tests were done with $100 \mathrm{ml}$ graduated cylinders as the settling vessel. The fluid was $100 \mathrm{ml}$ of water and the glass formers tested were 5 grams of as received Frit 320 or beads (-140 mesh, $-100+140$ mesh, or $-70+100$ mesh). In the first test, the glass formers were added to the 4 cylinders at the same time and relative settling times noted (non-shaken test). With the existing slurries, the four cylinders were then covered and shaken at the same time and settling observed. Table 3-1 gives the settling times of these two tests. Settling tests were then performed with these same glass formers in a Xanthan gum slurry after the cylinders and contents were shaken. All of these tests were filmed. The results are summarized in Table 3-2 with the level of material settling in the bottom of the graduated cylinder.

Table 3-1. First Frit 320/Beads Settling Test Results in Water

\begin{tabular}{|c|c|c|}
\hline Glass Former & $\begin{array}{c}\text { Settling Time - } \\
\text { Non-Shaken Test } \\
\text { (Seconds) }\end{array}$ & $\begin{array}{c}\text { Settling Time - } \\
\text { Shaken Test } \\
\text { (Seconds) }\end{array}$ \\
\hline Frit 320 & 104 & 72 \\
\hline Beads (-140 mesh) & 112 & 94 \\
\hline Beads (-100+140 mesh) & 37 & 27 \\
\hline Beads (-70+100 mesh) & 18 & 12 \\
\hline
\end{tabular}

Table 3-2. *First Frit 320/Beads Settling Test Results in Xanthan Gum Slurry

\begin{tabular}{|c|c|c|c|c|}
\hline $\begin{array}{c}\text { Test Time } \\
\text { (Minutes) }\end{array}$ & $\begin{array}{c}\text { Frit } 320 \\
\text { (as received) }\end{array}$ & $\begin{array}{c}\text { Beads } \\
(-140 \text { mesh })\end{array}$ & $\begin{array}{c}\text { Beads } \\
(-100+140 \text { mesh })\end{array}$ & $\begin{array}{c}\text { Beads } \\
(-70+100 \text { mesh })\end{array}$ \\
\hline 22 & None & None & $<1$ & $<1$ \\
\hline 42 & None & None & $<1$ & 4 \\
\hline 124 & 5 & None & 3 & 5 \\
\hline 413 & 7 & 3 & 3 & 5 \\
\hline 653 & 9 & 3 & 3 & 5 \\
\hline 1013 & 10 & 3 & 3 & 5 \\
\hline 1245 & 8 & 3 & 3 & 5 \\
\hline
\end{tabular}

* Note: Numbers cited are the levels $(\mathrm{ml})$ of material settled in the bottom of the graduated cylinders

The settling tests in water indicated that the Frit 320 and -140 mesh beads settled in similar times. The $-100+140$ mesh beads settled about 3 times faster. The $-70+100$ beads (largest size tested) settled twice as fast as the $-100+140$ mesh beads and about six to nine times faster than the Frit 320 and -140 mesh beads. In addition, the slurries in the $-100+140$ and $-70+100$ mesh beads became clear very quickly. This was because these two sized beads did not contain the fines that were in the Frit 320 and -140 mesh beads. 
The settling tests in the Xanthan gum slurry tests showed that the large -70+100 mesh beads settled fairly quickly in this thicker test slurry. The rest of the glass formers tested settled in similar fashion. The differences in level of material settled at the end the test is due in part to the different particle sizes that result in different amounts of packing of the glass formers. The Frit 320 tended to clump together and therefore may be the reason for the higher settling volume.

\subsubsection{Second Set of Settling Tests}

The second series of tests were performed exactly the same as the first series of tests per run plan SRNLITS-2005-0170. The main purpose of these tests was to better determine the impact of particle shape on settling behavior by comparing settling rates of similar sized frit and bead particles. Frit 320 sieved to $-80+100$ mesh and beads sieved to $-70+100$ mesh were tested in both water and the Xanthan gum slurry. After this Frit 320 sieved to $-100+140$ mesh and beads sieved to $-100+140$ mesh were tested in both slurries as well. The $-100+140$ mesh size was chosen to compare smaller sized glass former particles that may be beneficial for melt rate.

During the first non-shaken test in water, the settling times for the $-80+100$ mesh Frit 320 and $-70+100$ mesh beads were 21 and 14 seconds respectively (settling of fines in Frit 320 not considered). With the slurries then shaken, the settling times for the $-80+100$ mesh Frit 320 and $-70+100$ mesh beads were 18 and 12 seconds respectively. For the water tests, both tests showed that the two glass formers settled in similar order of magnitude times, but that the irregular shaped particles did settle somewhat slower. The results of the Xanthan gum slurry tests are shown in Table 3-3. There was no difference in settling times in the thicker Xanthan gum slurry. For DWPF operations, the two times should be deemed similar in both water and the Xanthan gum slurry.

Table 3-3. *Frit $320(-80+100$ mesh)/Beads (-70+100 mesh) Settling Test Results in Xanthan Gum Slurry

\begin{tabular}{|c|c|c|}
\hline $\begin{array}{c}\text { Test Time } \\
\text { (Minutes) }\end{array}$ & $\begin{array}{c}\text { Frit } 320 \\
(-80+100 \text { mesh })\end{array}$ & $\begin{array}{c}\text { Beads } \\
(-70+100 \text { mesh })\end{array}$ \\
\hline 5 & None & None \\
\hline 10 & None & None \\
\hline 15 & $<1$ & $<1$ \\
\hline 20 & 4 & 4 \\
\hline 25 & 5 & 4 \\
\hline 40 & 6 & 4 \\
\hline 155 & 6 & 4 \\
\hline 279 & 6 & 4 \\
\hline 1494 & 6 & 6 \\
\hline
\end{tabular}

* Note: Numbers cited are the levels (ml) of material settled in the bottom of the graduated cylinders

The above tests were repeated with Frit 320 sieved to $-100+140$ mesh and $-100+140$ mesh beads. For the water tests, the Frit 320 settled in 40 seconds and the beads settled in 20 seconds for both the non-shaken and shaken tests. The smaller Frit $320-100+140$ mesh particles settled about twice as fast as the -80 +100 mesh particles. The results of the Xanthan gum slurry tests are given in Table 3-4. The beads settled somewhat faster than the Frit 320 (layer $>1$ ml noted in 20 versus 40 minutes). It was difficult to see the layer in the Xanthan gum/Frit 320 mixture, and the layer may have been there earlier. For both the water and Xanthan tests with -100+140 mesh glass formers, the settling times were on the same order of magnitude with regards to DWPF operations. Settling behavior as noted in Section 3.4 (Slurry Addition to SME Impact) may be more important than these tests. In addition, the settling behavior noted during the Erosion Test (see Section 3.1.4) may be a better indicator of settling in the DWPF vessels as well. 
Table 3-4. *Frit 320 (-100+140 mesh)/Beads (-100+140 mesh) Settling Test Results in Xanthan Gum Slurry

\begin{tabular}{|c|c|c|}
\hline $\begin{array}{c}\text { Test Time } \\
\text { (Minutes) }\end{array}$ & $\begin{array}{c}\text { Frit } 320 \\
(-100+140 \text { mesh })\end{array}$ & $\begin{array}{c}\text { Beads } \\
(-100+140 \text { mesh })\end{array}$ \\
\hline 5 & 0 & 0 \\
\hline 10 & 0 & 0 \\
\hline 15 & $<1$ & 0 \\
\hline 20 & $<1$ & $3-4$ \\
\hline 25 & $<1$ & 4 \\
\hline 30 & $<1$ & 4 \\
\hline 35 & $<1$ & 4 \\
\hline 40 & 5 & 4 \\
\hline 45 & 5 & 4 \\
\hline 135 & 5 & 4 \\
\hline 1248 & 5 & 4 \\
\hline
\end{tabular}

* Note: Numbers cited are the levels (ml) of material settled in the bottom of the graduated cylinders

\subsubsection{SRAT Product Settling Tests}

The final planned settling test was run like the above tests in $100 \mathrm{ml}$ graduated cylinders but the settling fluid was SB3 SRAT material. Frit 320 sieved to $-100+140$ mesh and $-100+140$ mesh beads were tested. The targeted waste loading was $40 \%$ and the weight percent solids of the SRAT product with the glass formers added was about 45\%. The test was performed per run plan SRNL-ITS-2005-00181. Because the glass formers could not be seen in the dark colored SRAT product, samples of the slurries were taken with pipettes at the $50 \mathrm{ml}$ level at various times. The samples were measured for percent solids to give an indication of settling over time. The results of this test are given in Table 3-5. The data show that the settling of the beads may have been slightly more than the Frit 320 for the same sized particles.

Table 3-5. Settling Tests with SB3 SRAT Product

\begin{tabular}{|c|c|c|}
\hline $\begin{array}{c}\text { Settling Time } \\
\text { (Hours) }\end{array}$ & $\begin{array}{c}\text { Wt\% Solids of } \\
\text { SB3/Frit 320 } \\
(-100+140 \text { mesh })\end{array}$ & $\begin{array}{c}\text { Wt\% Solids of } \\
\text { SB3/Beads } \\
(-100+140 \text { mesh })\end{array}$ \\
\hline 2 & 46.52 & 47.17 \\
\hline 4 & 45.79 & 48.10 \\
\hline 6 & 45.67 & 47.36 \\
\hline 24 & 45.95 & 49.26 \\
\hline
\end{tabular}

The results of the settling rate tests lead to a decision to use $-100+140$ mesh beads for most of the remaining tests. This was based on several findings. First, the $-100+140$ mesh beads settled at about the same rate as the larger $-80+100$ mesh Frit 320 (largest sized particles in as-received frit) in both the water and Xanthan gum tests. Secondly, the use of $-100+140$ mesh beads gives conservatism to the tests that followed (feed rheology, erosion, SME slurry addition, and melt rate) due to lack of fines in the beads tested.

\subsubsection{Erosion Tests - Settling Observations}

Before the erosion test was started, the relative settling behavior for the Frit 320 and beads $(-100+140$ mesh) were also determined by lowering the agitator speed for each vessel until a layer of water was observed at the top of the glass former/water mixture. At an agitator speed as low as $300 \mathrm{rpm}$, there was 
no sign of glass former settling. The first sign of a small layer of only water at the top the slurry in both vessels was observed at $250 \mathrm{rpm}$. At $200 \mathrm{rpm}$, there were water layers of 1 and 0.25 inches respectively in the bead and Frit 320 vessels. This may indicate that the beads required slightly more agitation than the Frit 320, but the settling behavior of both was very similar when in a stirred vessel with water.

\subsection{Impact of Beads on Feed Rheology}

The rheograms from the SB3 SRAT product (FPMR-134A) mixed with Frit 320 or various sized beads (-140 mesh, $-100+140$ mesh, or $-70+100$ mesh) to achieve $40 \%$ waste loading and 45 weight percent solids are given below in Figures 3-1 to 3-4. These SME products were made per run plan SRNL-ITS2005-00182. Table 3-6 summarizes the yield stress (Pa) and consistency (cP) for each run. The values cited in Table 3-6 are the average of the two runs for each SME product. Based on the relative short time to perform each rheogram (about 30 minutes) and the settling rates noted in Section 3.1.3 for beads and frit in SRAT product, neither the beads nor the Frit 320 should have settled during the running of these rheograms.

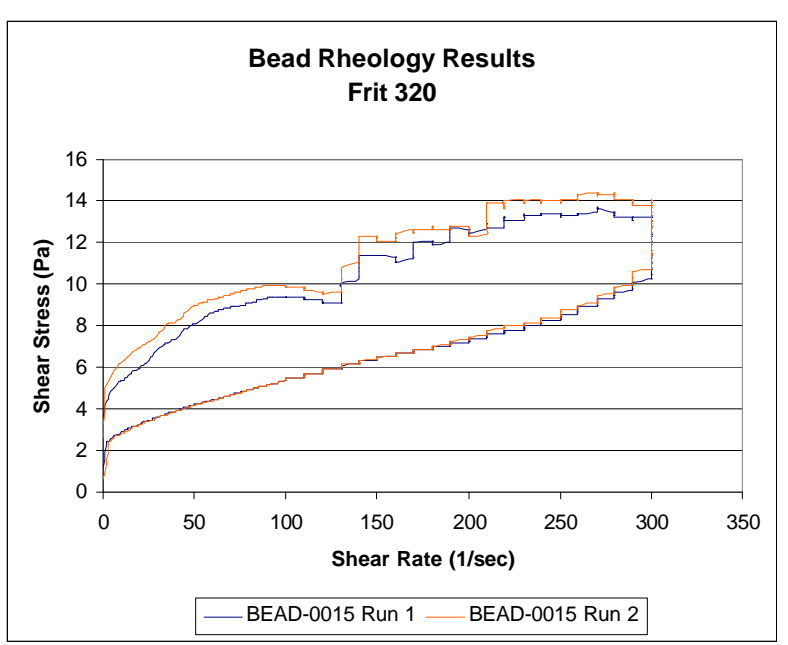

Figure 3-1. SB3/Frit 320 Rheogram

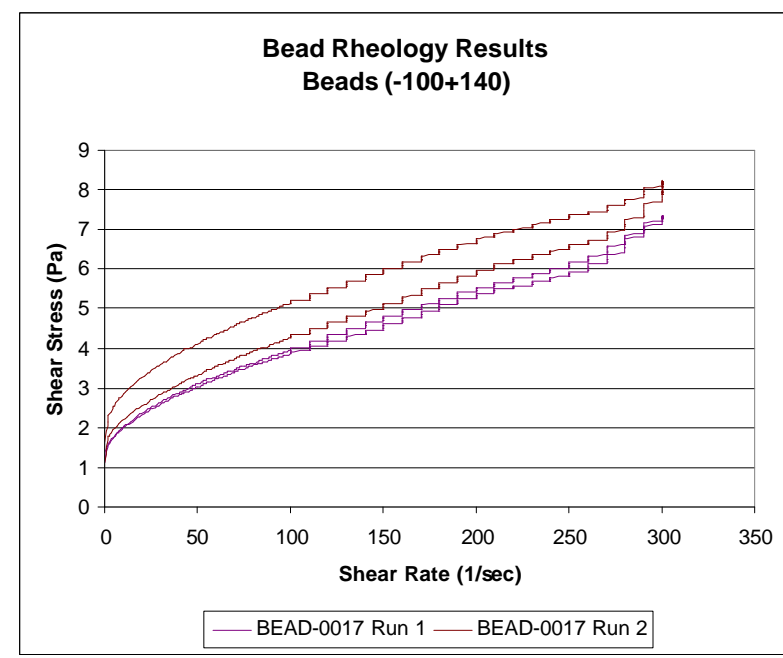

Figure 3-3. SB3/Bead (-100+140) Rheogram

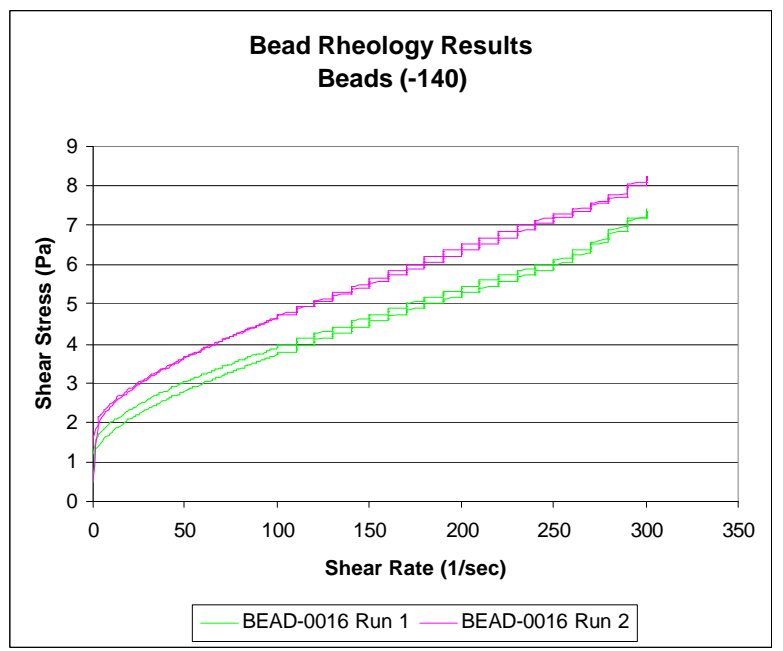

Figure 3-2. SB3/Bead (-140) Rheogram

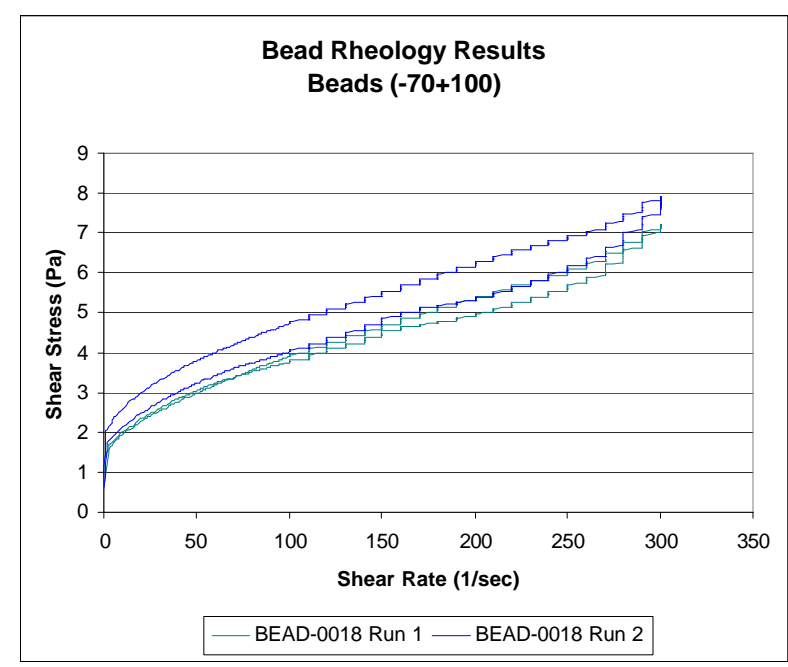

Figure 3-4. SB3/Bead (-70+100) Rheogram 
Table 3-6. Impact of Frit 320 and Various Sized Beads on Rheology of SB3 SME Product

\begin{tabular}{|c|c|c|c|}
\hline Frit/Bead (Sample ID) & $\begin{array}{c}\text { Yield Stress } \\
\text { (Pa) }\end{array}$ & $\begin{array}{c}\text { Consistency } \\
(\mathbf{c P})\end{array}$ & $\begin{array}{c}\text { * \% Reduction in } \\
\text { Yield Stress } \\
\text { /Consistency }\end{array}$ \\
\hline Frit 320 (Bead-0015) & 3.26 & 20.53 & N.A. \\
\hline-140 Bead (Bead-0016) & 2.64 & 16.05 & $23 / 28$ \\
\hline$-100+140$ Bead (Bead-0017) & 2.51 & 15.27 & $30 / 34$ \\
\hline$-70+100$ Bead (Bead -0018) & 2.61 & 12.88 & $25 / 59$ \\
\hline
\end{tabular}

* Relative to Frit 320 SME product

There was a reduction in both yield stress (23-30 percent) and consistency (28-59 percent) when beads were used in the place of frit. However, yield stress was not significantly impacted by the bead particle size.

The second series of rheology tests were performed using SB3 SRAT/SME product from two different runs per run plan SRNL-ITS-2005-00192 (see Section 2.2 for feed preparation details). The first run utilized Frit 320 as received from DWPF while the second run utilized Frit 320 that had been processed into spheres and sized to $-100+200$ mesh. SB3 baseline sludge simulant was utilized during the testing. The measured waste loading for both SME product was about $37 \%$ and the measured weight percent solids was about $52 \%$.

The SME product samples were analyzed for rheological properties at two solids contents. The first set of samples was performed without dilution from the SME product sample while the second set was diluted to $45 \%$ total solids. Numerical results are shown in Table 3-7 while the individual flow curves are shown in Figures 3-5 and 3-6. Each curve was fitted using the Bingham Plastic model. The up curves were not fitted for the $45 \%$ solids content samples due to the shape of the flow curve, but the values are included in Table 3-7. The results indicate that the beads lowered the yield stress for the down curve for the $45 \mathrm{wt} \%$ samples by approximately $6 \%$ and the $52 \mathrm{wt} \%$ solids samples by 10 to $17 \%$.

Table 3-7. Rheological Results for SME Products

\begin{tabular}{|c|c|c|c|c|}
\hline & \multicolumn{2}{|c|}{ Beads } & \multicolumn{2}{c|}{ Frit } \\
\hline Up Curve & $45 \%$ & $52 \%$ & $45 \%$ & $52 \%$ \\
\hline Yield Stress (Pa) & 14.7 & 34.0 & 13.2 & 41.1 \\
\hline Consistency (cP) & 18.9 & 48.2 & 27.3 & 52.2 \\
\hline & & & & \\
\hline Down Curve & $45 \%$ & $52 \%$ & $45 \%$ & $52 \%$ \\
\hline Yield Stress (Pa) & 15.0 & 41.0 & 16.8 & 46.1 \\
\hline Consistency (cP) & 50.7 & 29.9 & 45.8 & 36.3 \\
\hline
\end{tabular}




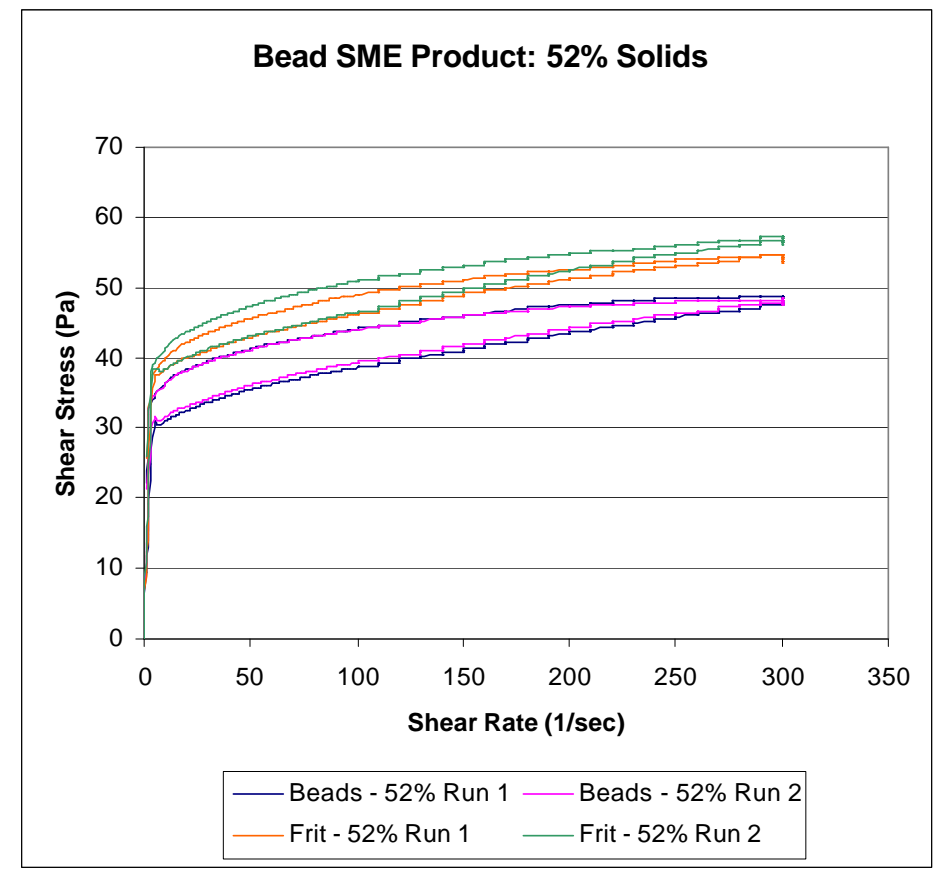

Figure 3-5. Flow Curves for 52 Weight \% Solids SME Bead 320 and Frit 320 Products

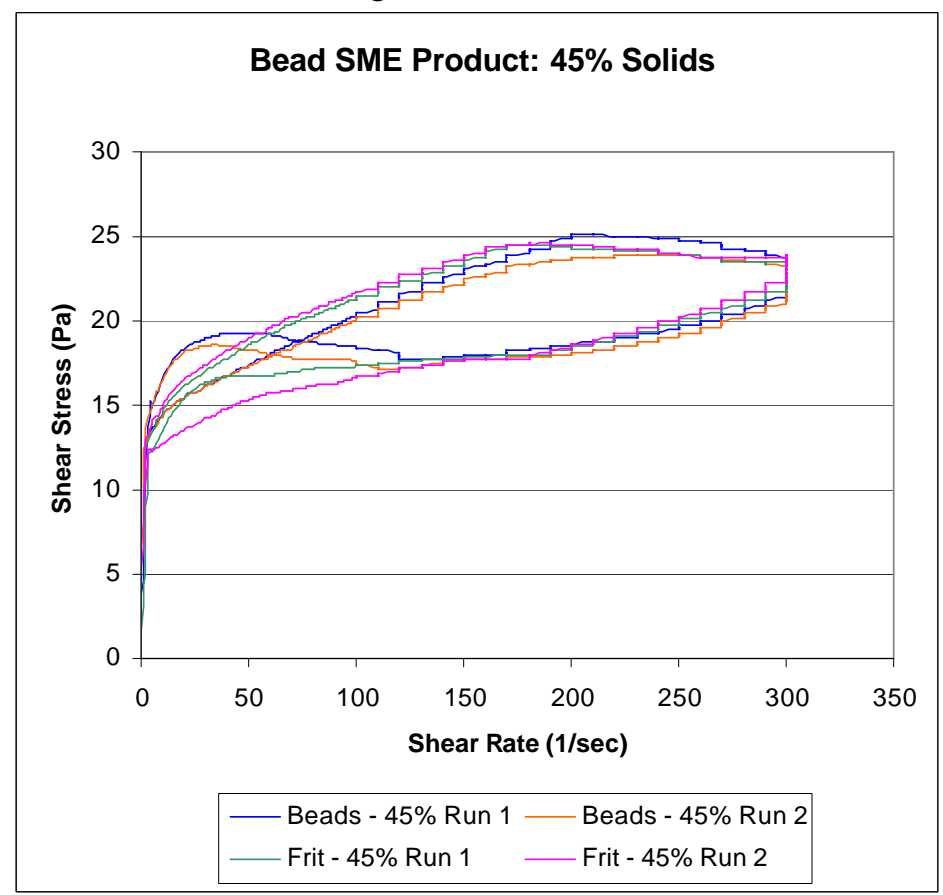

Figure 3-6. Flow Curves for 45 Weight \% Solids SME Bead 320 and Frit 320 Products

\subsection{Impact of Beads on Erosion}

The two agitator blades were weighed before the erosion test began and after 14 days in the vessels with continuous agitation at $350 \mathrm{rpm}$ in a 50 weight percent solids slurry of water and either Frit 320 or beads $(-100+140$ mesh). A summary of the weights are given in Table 3-8. The results show a slight increase in erosion with the beads versus the Frit 320, although the overall weight loss for both agitators was fairly small. Figure 3-7 shows the two test agitators after the test. The shiny appearance of the Frit 320 test 
agitator relative to the bead test agitator indicates that the Frit 320 was more erosive, which does not agree with the percent weight losses. No explanation for these two contradicting findings was made.

Before the test it was expected that the Frit 320 would be more erosive than the beads (based on PSD information). Due to the erosion test results, samples were taken from both slurries to determine if the PSD's was changed for either the beads or frit during the test. A PSD analysis was run on the bead slurry, but the Frit 320 clumped together and there were concerns that the amount of force needed to break the clumps would break the particles. The beads had a similar PSD as to that measured before the test as previously shown in Figure 2.1. More formal erosion tests (such as ASTM erosion tests) may be required, but this initial test at least indicates that beads should not cause a significant increase in erosion in the DWPF vessels, agitators, or piping.

Table 3-8. Impact of Beads Agitator Erosion Test

\begin{tabular}{|c|c|c|c|c|}
\hline Agitator Test & $\begin{array}{c}\text { Pre-Test } \\
\text { Weight (gms) }\end{array}$ & $\begin{array}{c}\text { Post-Test } \\
\text { Weight (gms) }\end{array}$ & $\begin{array}{c}\text { Weight } \\
\text { Loss (gms) }\end{array}$ & $\begin{array}{c}\text { Percent Weight } \\
\text { Loss }\end{array}$ \\
\hline Frit 320 & 117.3894 & 116.4964 & 0.8930 & 0.76 \\
\hline Beads & 115.7417 & 114.4032 & 1.3385 & 1.16 \\
\hline
\end{tabular}

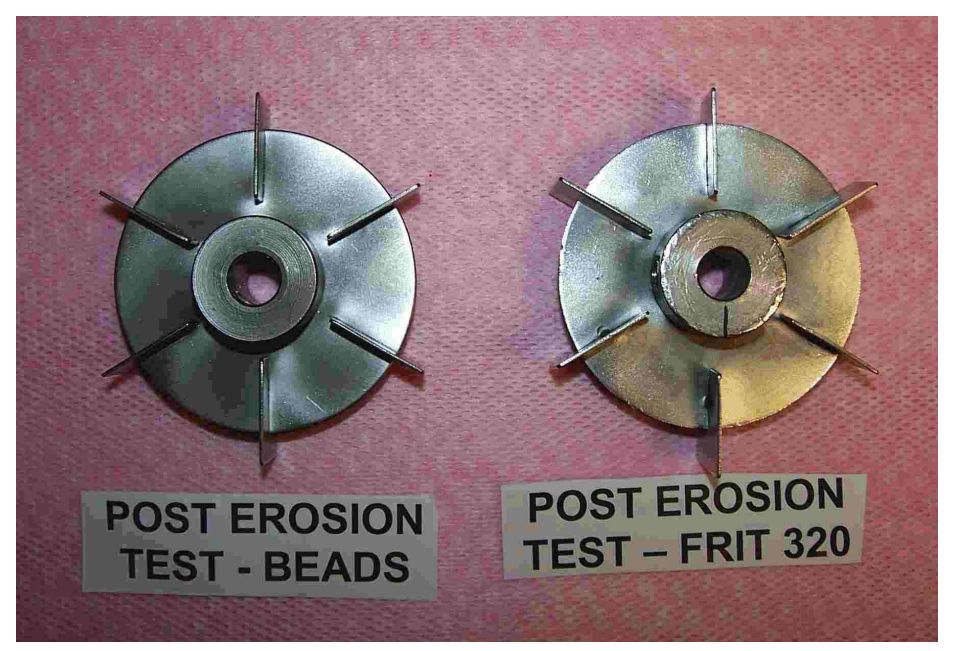

Figure 3-7. Post Erosion Test Agitator Blades

\subsection{Impact of Beads on Slurry Addition to SME}

A calibration check was performed before the run on the test rig flow melter (with water) by pumping water into a beaker and noting the amount actually pumped in a period of time. At indicated rates between 2.7 and $5.2 \mathrm{gpm}$, the indicated flow from the flow meter was within 2-4\% lower than the actual flow.

Before starting the actual recirculation test with beads (-100+140 mesh), a minimum agitator rate was determined for the 50 weight percent solids mixture of water and beads. An agitator speed of $450 \mathrm{rpm}$ was required and the torque on the agitator was $30 \mathrm{oz}-\mathrm{in}$. A slight mound was under the three pipes (one suction and two return) in the feed tank that caused an area of low mixing in the tank. This mound grew larger with lower agitator speeds. With the bypass line valve fully closed, a flow of about $8 \mathrm{gpm}$ was achieved. Lower flow rates were obtained by opening the bypass ball valve and adjusting to get the desired flow rate. This was done until settling was noted in the horizontal recirculation section of the clear $3 / 4$ inch PVC pipe. At each flow rate, the pump power, pump amps, line pressure (digital pressure 
meter reading), flow rate, and comments on settling in the clear pipe were noted. As discussed in Section 2.4, more beads were added to make a 55 weight percent solids mixture and the same steps were followed. Finally, beads were added to make a 60 weight percent solids mixture and the same steps repeated.

After testing the beads, the rig was drained and Frit 320 was tested in a 50 weight percent mixture. An agitator speed of $522 \mathrm{rpm}$ (torque reading not working) was required to keep frit from mounding in the tank at the same location observed for the beads. Tests with Frit 320 at higher weight percent solids were not done as the nitrile pump impeller was worn too much by the abrasive frit particles. The highest flow rate possible was about $6.5 \mathrm{gpm}$ with the bypass valve fully closed. This lower rate may have been due to some erosion of this impeller even as the test was just starting. Table 3-9 summarizes the data/comments taken during these tests. One important positive observation made was that after stopping flow, flow for the beads mixture could be regained. This was tried for the Frit 320 mixture, but flow could not be restarted.

Table 3-9. Summary of Bead/Frit Mixture Recirculation Test

\begin{tabular}{|c|c|c|c|c|}
\hline \multicolumn{5}{|c|}{ BEADS - 50\% SOLIDS } \\
\hline $\begin{array}{l}\text { Pump } \\
\text { Watts }\end{array}$ & $\begin{array}{l}\text { Pump } \\
\text { Amps }\end{array}$ & $\begin{array}{l}\text { Line Press } \\
\text { (inches wc) }\end{array}$ & $\begin{array}{c}\text { Flow } \\
\text { (gpm) }\end{array}$ & Observations \\
\hline 320 & 3.49 & 106 & 8 & No settling \\
\hline 263 & 3.04 & 64 & 6 & No settling \\
\hline 263 & 3.02 & 51 & 5 & No settling \\
\hline 266 & 3.03 & 44 & 4.5 & Bottom slowly moving relative to top \\
\hline 263 & 3.02 & 40 & 4 & Some settling (small amount) \\
\hline 266 & 3.06 & 42 & 3.75 & Some settling (more than $4 \mathrm{gpm}$ test) \\
\hline 279 & 3.14 & 43 & 3.5 & Settling (more than $3.75 \mathrm{gpm}$ test) \\
\hline- & - & 46 & 3 & Solids not moving or just barely (stop and start) \\
\hline 246 & 2.89 & 50 & 2.5 & Zero flow on bottom, top half flowing \\
\hline \multicolumn{5}{|c|}{ BEADS - $55 \%$ SOLIDS } \\
\hline 271 & 3.07 & 105 & 7.5 & No settling \\
\hline 253 & 2.94 & 69 & 6 & No settling (slightly slower on bottom) \\
\hline 248 & 2.48 & 56 & 5 & Same as $6 \mathrm{gpm}$ test \\
\hline 244 & 2.88 & 49 & 4 & First sign of layer starting and stopping in bottom $15 \%$ of pipe \\
\hline 244 & 2.87 & 50 & 3.5 & More stopping and starting in bottom $25 \%$ of pipe \\
\hline- & - & 53 & 3 & Bottom $50 \%$ in pipe stopping/starting \\
\hline 260 & 3.00 & 103 & 7.7 & Increased flow, no settling (able to recover from settling at low flows) \\
\hline \multicolumn{5}{|c|}{ BEADS - 60\% SOLIDS } \\
\hline 270 & 3.06 & 111 & 7.5 & No settling \\
\hline 257 & 2.96 & 80 & 6 & No settling, slightly slower flow on bottom \\
\hline 252 & 2.93 & 66 & 5 & No settling, bottom never stops but is slow \\
\hline 248 & 2.91 & 62 & 4 & Some stop/start flow in bottom $20 \%$ of pipe \\
\hline 249 & 2.91 & 61 & 3.5 & Same as $4 \mathrm{gpm}$ test \\
\hline 250 & 2.91 & 62 & 3 & Worse than 3.5 gpm test (bottom $40 \%$ stop/start) \\
\hline- & - & - & 2.5 & Tried 2.5 gpm but couldn't control flow due to settling in lines \\
\hline \multicolumn{5}{|c|}{ FRIT $320-50 \%$ SOLIDS } \\
\hline 279 & 3.13 & 90 & 6.5 & Bottom $12 \%$ moving slower \\
\hline 210 & 2.65 & 73 & 5 & No comments \\
\hline- & - & 70 & 4.5 & Bottom $33 \%$ in pipe moving slower \\
\hline- & - & 66 & 4 & $50 \%$ of pipe is solids, flow dropped to 2.5 , had to close bypass valve \\
\hline- & - & 73 & 3.5 & Bottom 33\% in pipe stopping and starting (opened valve to get 3.5) \\
\hline- & - & 73 & 3 & Bottom $40 \%$ in pipe stopping and starting \\
\hline- & - & 72 & 2.5 & Bottom $40 \%$ in pipe barely moving \\
\hline- & - & 76 & 2 & Bottom $50 \%$ in pipe barely moving \\
\hline- & - & 78 & 1.8 & Same as $2 \mathrm{gpm}$ test \\
\hline 164 & 2.36 & 72 & 3.7 & Had to close bypass valve again \\
\hline
\end{tabular}


Overall, the data shows that the line pressure increased as the solids were increased for the same flow rate. In addition, the line pressure was higher for Frit 320 than the beads at the same solids level and flow. With the observations, a determination of minimum velocity to prevent settling could be done, but a graph of the line pressures (see Figure 3-8) versus velocity (not flow) for the various tests was deemed to more objective. The graph shows that the inflection point in pressure drop is about the same for the beads and Frit 320 (about $2.5 \mathrm{ft} / \mathrm{sec}$ ). This inflection point can be used as it is caused by the beginning of the settling of glass formers that starts to decrease the effective pipe inner diameter, thereby resulting in increasing line pressure. Further decreases in flow result in additional settling and even further reductions in the effective pipe diameter. This indicates that the bead (-100+140 mesh) slurry would not require higher flows rates than frit slurry at DWPF during transfers. Another key finding was that the pump impeller was not significantly damaged by the bead slurry, while the Frit 320 slurry rapidly destroyed the impeller. Evidence of this was first observed when black particles were seen in the Frit 320 slurry being recirculated and then was confirmed by a post-test inspection of the impeller. Finally, as pointed out before, the pumping of bead slurry can be recovered even if flow is stopped. This was not tried with the Frit 320 slurry due to the damage to the nitrile pump impeller.

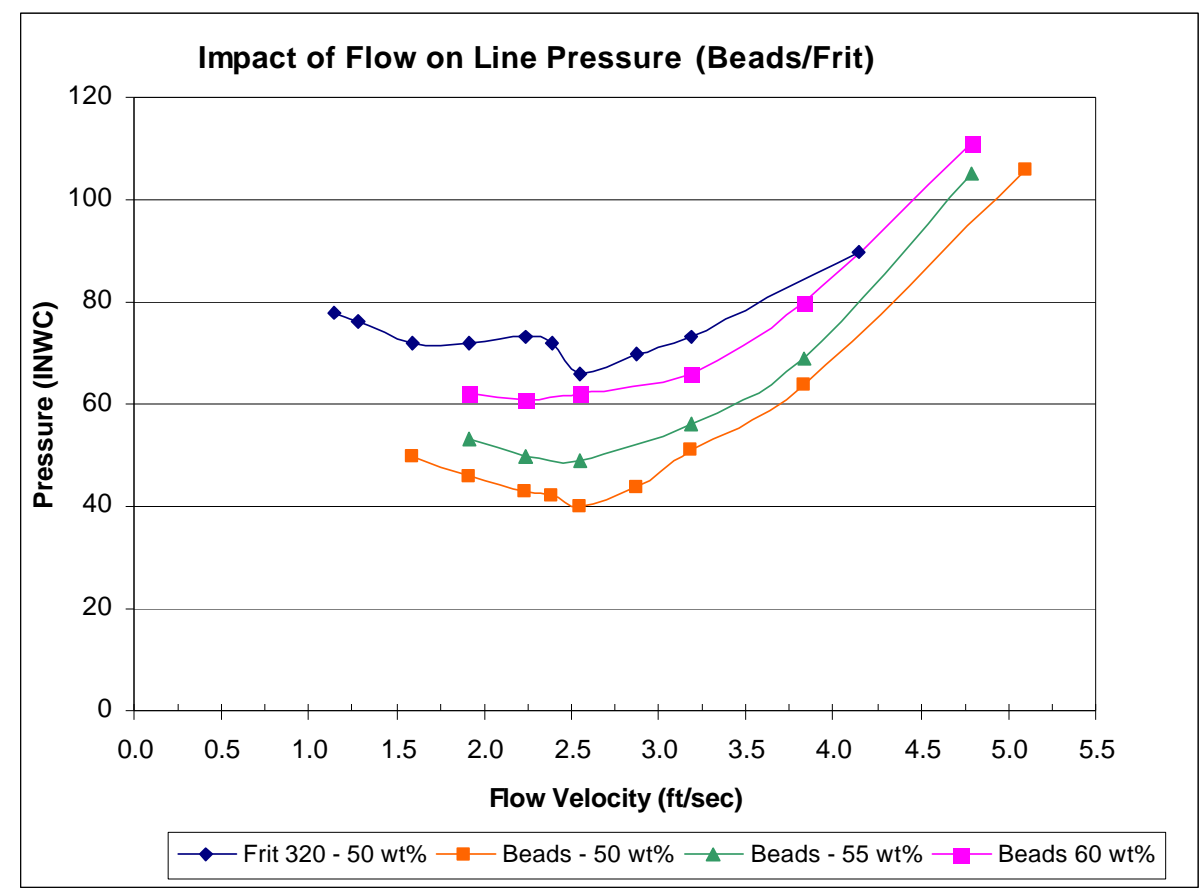

Figure 3-8. Impact of Flow on Line Pressure for Bead and Frit 320 Mixtures

\subsection{Impact of Beads on Melt Rate}

The two beakers containing SB3/Frit 320 and SB3/Bead (-100+200) 320 feed were heated in the MRF at $1150^{\circ} \mathrm{C}$ for 50 minutes. The beakers were removed and allowed to cool. The appearances of the beakers after the tests were significantly different. The Frit 320 material had higher bed expansion (see top right picture in Figure 3-9). The Bead 320 material had a ring of partially melted material above the molten glass (top left picture in Figure 3-9). Cross-sections of the two beakers are shown in the two bottom pictures of Figure 3-9. The SB3/Bead 320 and SB3/Frit 320 had similar linear melt rates (LMR) of 0.45 and 0.47 inches/hour (basically the same melt rate). The differences in appearance, however, indicated that the beads may impact cold cap behavior. Therefore slurry-fed tests in the SMRF would have to be performed to better determine the impact of melt rate by beaded glass formers. 


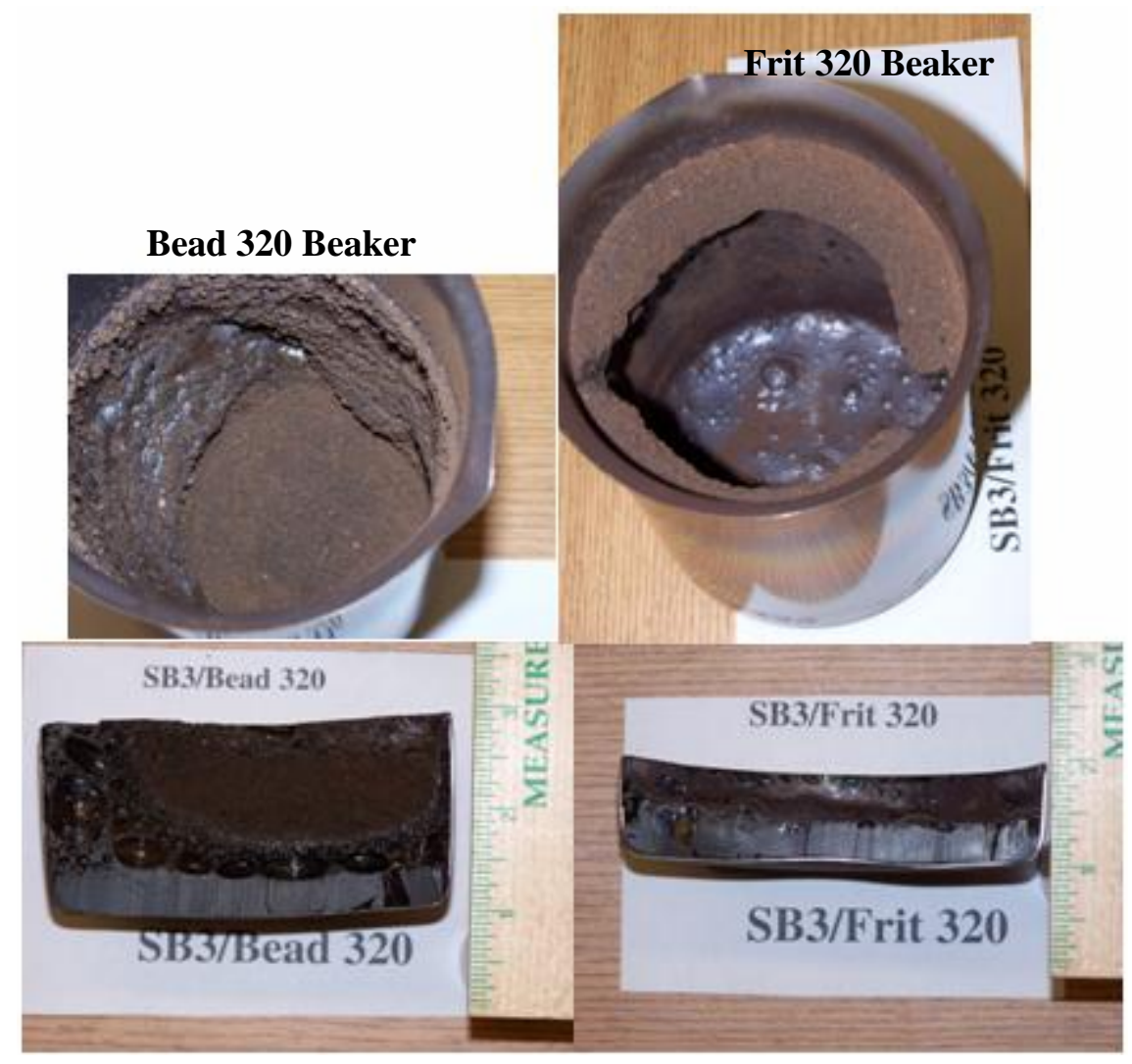

Figure 3-9. Top Views of the SB3/Bead 320 and SB3/Frit 320 MRF Beakers and the Cross-Sections of the Beakers 


\subsection{CONCLUSIONS}

The following conclusions are given as a result of the work discussed in this report. The conclusions are divided into the major process impacts examined.

\section{Overall}

- The testing did not show any problems with the use of beads with regards to process impacts investigated as listed below.

- Because the beads were shown to reduce the rheological properties of the SME product (or melter feed), a higher weight percent solids feed could be processed in the melter. From past pilot scale testing ${ }^{3}$ as well as limited DWPF operational experience, this could increase the DWPF melt rate by about 2-5 percent for every weight percent solids increase allowed.

\section{Settling Behavior}

- For the water slurry settling tests, Frit 320 and -140 mesh beads had similar settling rates. The $-100+140$ settled about three times as fast and the largest beads tested $(-70+100$ mesh) settled about six times faster than Frit 320. If the Frit 320 was sieved to match the size of the beads, then the beads had similar settling rates.

- For the clear Xanthan gum slurry settling tests (used to mimic the rheology of the SME material), the $-70+100$ mesh beads settled relatively quickly even in this thicker slurry. The other sized beads $(-100+140$ and $-70+100$ mesh) settled at about the same rate as Frit 320 . When similar sized Frit 320 and beads were tested, the settling rates were again similar.

- For the settling test in which beads and Frit 320 (both -100+140 mesh) were mixed with simulated SB3 SRAT product, the beads settled slightly faster than the Frit 320.

- During the determination of the required agitator speed for Frit 320 and -100+140 mesh beads, it was found that the required agitator speed was about the same for the two different shaped glass formers.

- The results of the settling rate tests lead to a decision to use $-100+140$ mesh beads for most of the remaining tests. This was based on several findings. First, the $-100+140$ mesh beads settled at the same rate as the larger $-80+100$ mesh Frit 320 (largest sized particles in as-received frit). Secondly, the use of -100+140 mesh beads gives conservatism to the tests that followed (feed rheology, erosion, SME slurry addition, and melt rate) due to lack of fines in the beads tested.

\section{Rheology}

- For the tests where Frit 320 and various sized beads (-140 mesh, -100+140 mesh, -70+100 mesh) were added to SB3 SRAT product, beads reduced both yield stress (23-30 percent) and consistency (28-59 percent).

- Neither yield stress nor consistency was significantly impacted by the bead particle size.

- For SRAT/SME processing with SB3 simulant, the use of Bead 320 (only -100+200 mesh tested) improved the rheology versus Frit 320 for the $45 \mathrm{wt} \%$ samples by approximately $6 \%$ and the 52 wt $\%$ solids samples by 10 to $17 \%$.

\section{Erosion}

- The results show a slight increase in erosion with the beads (-100+140 mesh) versus the Frit 320, although the overall weight losses for both agitators were fairly small. The shiny appearance of the Frit 320 test agitator relative to the bead test agitator indicated that the Frit 320 was more erosive, which did not agree with the percent weight losses. No explanation for these two contradicting findings was made. 
Slurry Addition to SME

- For the recirculation test, the line pressure increased as the solids were increased for the same flow rate (only $-100+140$ mesh beads tested at various weight percent solids).

- For the recirculation test, the line pressure was higher for Frit 320 than beads (-100+140 mesh) at the same solids level and flow.

- Line pressures measured for the recirculation tests show that the inflection point in line pressure is about the same for the beads and Frit $320(2.5 \mathrm{ft} / \mathrm{sec})$. This increase in pressure as flow is reduced is an indication that the glass formers are settling and therefore the minimum flow velocity for both the Frit 320 and $-100+140$ mesh beads is about $2.5 \mathrm{ft} / \mathrm{sec}$.

Melt Rate

- The SB3/Bead (-100+200 mesh) 320 and SB3/Frit 320 had similar linear melt rates of 0.45 and 0.47 inches/hour (basically the same melt rate). The differences in appearance, however, indicate that the beads may impact the cold cap behavior.

\subsection{RECOMMENDATIONS/PATH FORWARD}

The following recommendations are given concerning investigating the use of beads in place of frit for the glass former used in the DWPF.

- Overall, the use of beads in DWPF should be further investigated to help achieve higher melt rates and waste throughputs.

- More formal erosion tests (such as ASTM erosion tests) should be run to better determine the impact of beads on the erosion of the DWPF vessels, piping, and agitators that would process slurries containing beads.

- Perform slurry-fed tests in the SMRF to better determine the impact of melt rate by beaded glass formers. Testing in the Cold Cap Evaluation Furnace (CEF) should also be considered (when the CEF is completed) to determine the impact of beads on the behavior of the cold cap.

- Rheology and settling tests with actual DWPF sludge SRAT product should be considered before beads are recommended for use in the DWPF. 


\subsection{REFERENCES}

1. Stone, ME and RF Schumacher. 2004. Preliminary Evaluation of Glass Former Morphology Impacts on Rheological Properties of Simulated DWPF Melter Feed Slurries (U), WSRC-TR2004-00337, Westinghouse Savannah River Company, Aiken, South Carolina.

2. Smith, ME, DH Miller, and TH Lorier. 2004. The Impact of Feed Preparation Acid Stoichiometry and REDOX on Melt Rate for the SB3-Frit 418 Feed System (U), WSRC-TR-2004-00350, Westinghouse Savannah River Company, Aiken, South Carolina.

3. Young, SR and DF Bickford. 1996. A Review of DWPF Pilot Melter Experience - Melt Rate and Associated Parameters (U), WSRC-TR-96-0405, Westinghouse Savannah River Company, Aiken, South Carolina.

4. Brown, NP and NI Heywood. 1991. Slurry Handling Design of Solid - Liquid Systems, $1^{\text {st }}$ edition, Elsevier Applied Science, New York.

5. Abulnaga, B. 2002. Slurry Systems Handbook, $1^{\text {st }}$ edition, McGraw Hill, New York.

6. Lorier, TH, TM Jones, and DC Witt. 2002. Melt Rate Testing for the DWPF: Summary of FY02 Testing (U), WSRC-TR-2002-00545, Westinghouse Savannah River Company, Aiken, South Carolina.

7. Lambert, DP and ME Stone. 2005. Feed Preparation for Source of Alkali Melt Rate Tests (U), WSRC-TR-2005-00080, Westinghouse Savannah River Company, Aiken, South Carolina. 
APPENDIX A - ANALYSES OF SRAT PRODUCT FPMR-0134A USED FOR SETTLING TEST

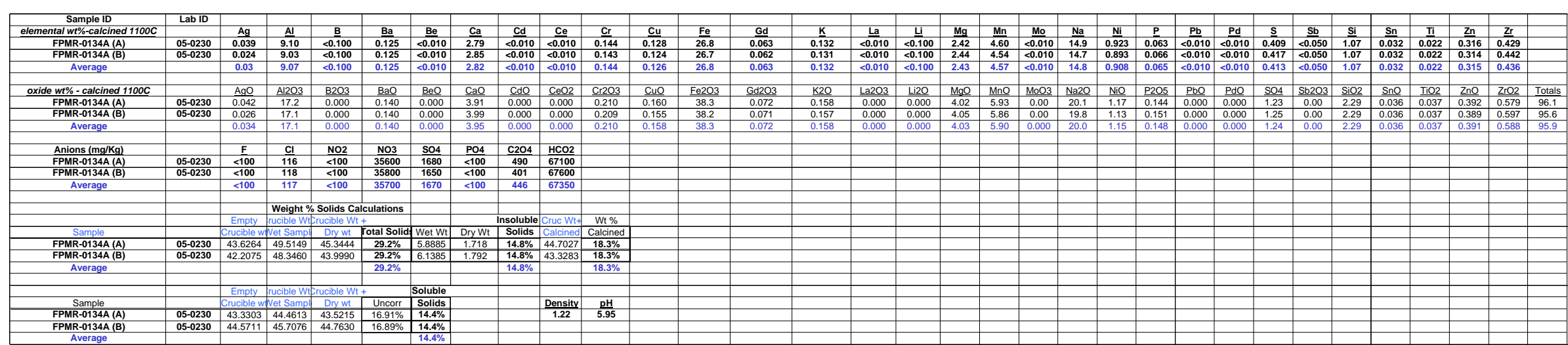


WSRC-TR-2005-00418

APPENDIX B - ADDITIONAL DETAILS FOR IMPACT OF BEADS SRAT/SME RUNS 


\section{Formate/Nitrite Conversions}

A mass balance was performed for formate and nitrate for the SRAT cycle. Based on the mass balance, the percentage of the formate lost during the SRAT cycle was calculated as well as the percentage of nitrite that was converted to nitrate, as shown in Table B-1. These values compare well with a previous SB3 run (Source of Alkali - SOA), which was conducted with the MWWT in dewater mode during acid addition. $^{7}$

Table B-1. Formic Destruction and Nitrite Conversion

\begin{tabular}{|l|c|c|c|}
\hline & SB3-Bead & SB3-Frit & $\begin{array}{c}\text { SB3 Baseline } \\
\text { from SOA } \\
\text { Tests }\end{array}$ \\
\hline Formate Destruction (\%) & 14.7 & 12.9 & 12.9 \\
\hline Nitrite Conversion (\%) & 22.5 & 26.2 & 25.0 \\
\hline
\end{tabular}

\section{Off-Gas Analysis}

Gas chromatographs recorded the off-gas composition of both SRAT and SME cycles. The off-gas analysis from the two runs was nearly identical and was compared to the results from earlier Source of Alkali (SOA) runs. ${ }^{7}$ The SOA baseline run was identical to the two runs conducted in this testing except that the MWWT was in the dewater position during acid addition for the SOA runs and was in reflux position for this testing. A comparison between the results from this testing and the SOA tests was conducted to determine the impact of reflux versus dewater during acid addition. This comparison was conducted for the SRAT cycles only as the SME cycle was not performed during SOA testing. The bead run data were used for the comparison except for the $\mathrm{CO}_{2}$ data.

A couple of issues were noted with the off-gas data from the bead testing. First, the nitrous oxide peaks were confused with a peak assumed to be water vapor during one of the runs leading to erroneously high readings. Second, the carbon dioxide data on one of the runs appears to be low based on the postcalibration check of the instruments. The collection of NO concentration data was inconsistent during the SOA baseline run and was not used in the comparison. Overall, however, the data appears to be of high quality. All charts are plotted with the end of formic acid shown at time zero.

\section{Hydrogen}

Very small amounts of hydrogen were detected during the test runs, as shown in Figure B-1. During the SRAT cycle, two very small peaks were detected in the run $\mathrm{w} /$ beads while the frit run did not have a hydrogen peak. Small peaks of hydrogen were noted after each frit addition during the SME cycle. Significant amounts of hydrogen were noted during the SOA baseline run, as shown in Figure B-2. The timing of the initial hydrogen peaks was the same for both runs. The second peak in the bead run does not have a corresponding peak in the SOA baseline run, but a second peak was noted (see Figure B-3) at this time during a previously run 4\% SOA test (this peak was chopped by the end of the SRAT cycle).

It should be noted that the size of the hydrogen peak during the SOA baseline run did not match the trend noted during the SOA testing in that increased sodium content in the sludge led to higher hydrogen peaks for other runs. The baseline run had a peak between the two less washed (and higher sodium) runs. The peaks noted in the bead run fell between the less washed and more washed runs, following the trend noted during the SOA tests for most runs. This timing provides evidence that the small peaks noted are hydrogen peaks and not the result of instrument noise. 


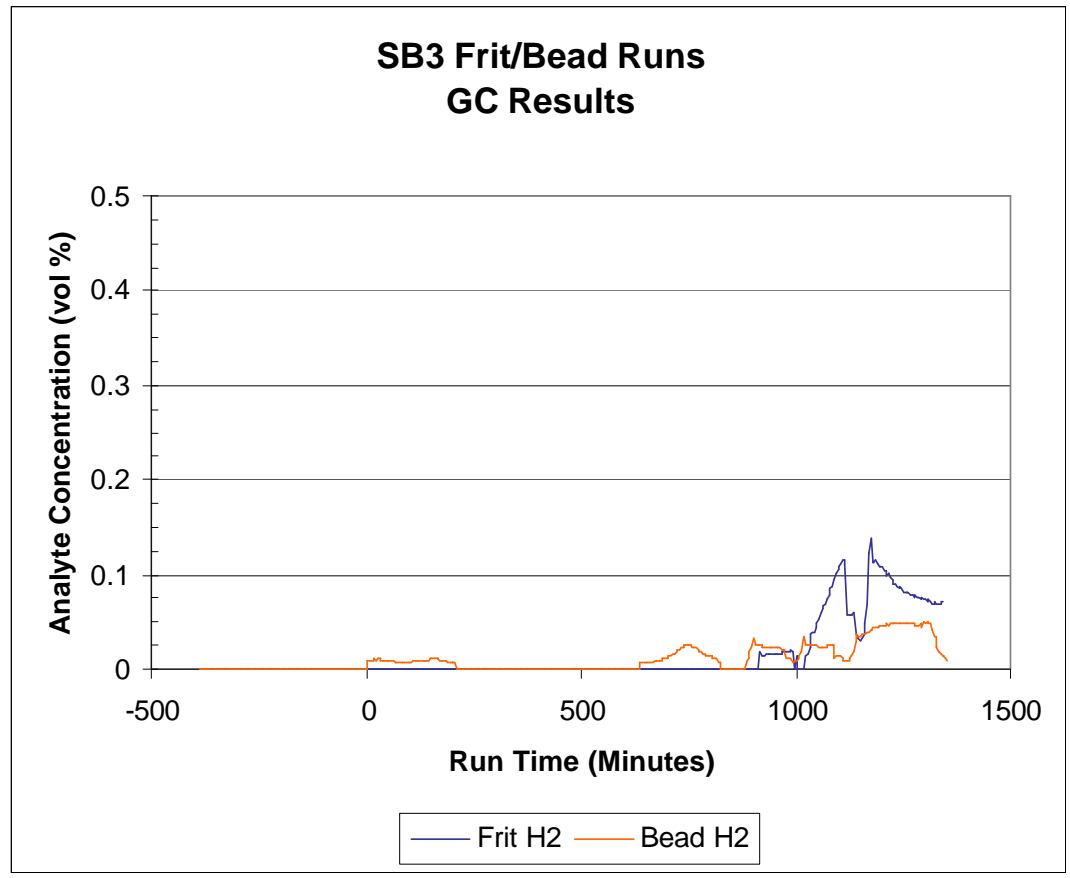

Figure B-1. Hydrogen during Frit/Bead Runs

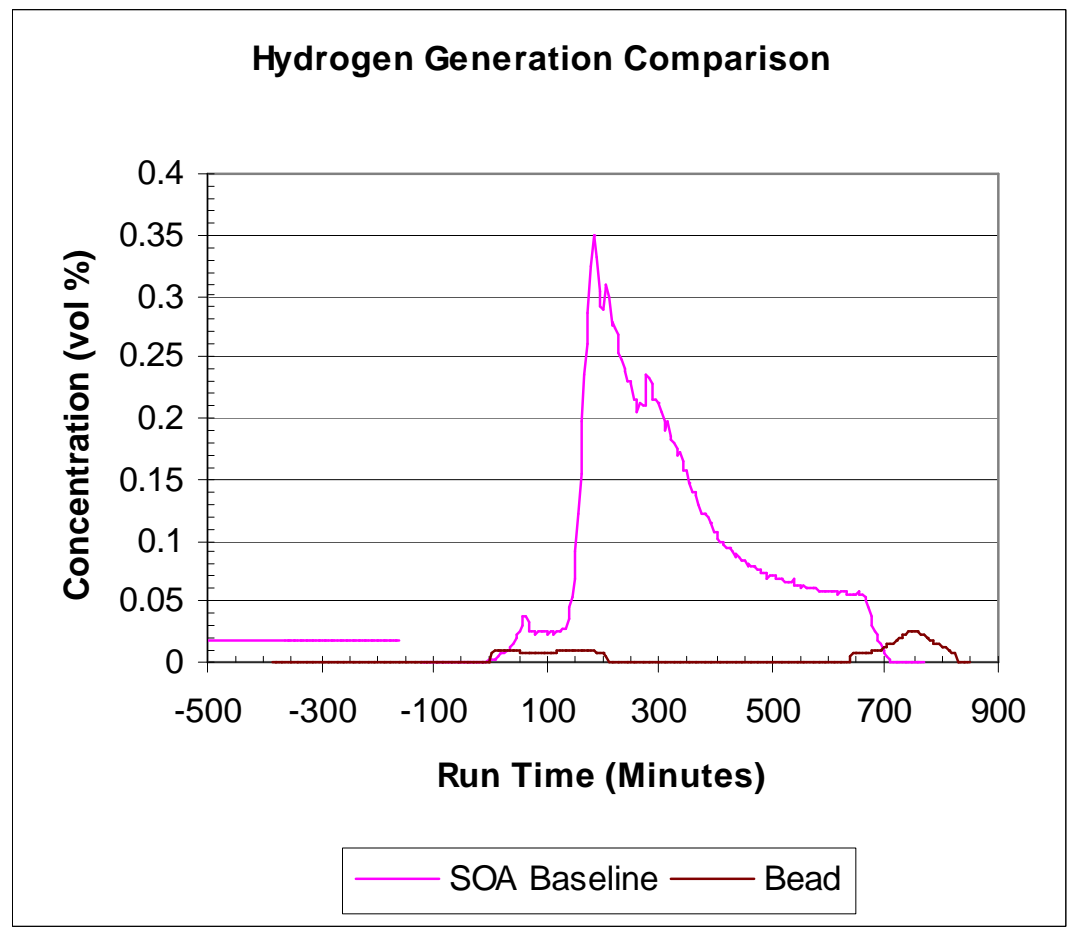

Figure B-2. Hydrogen during SOA Baseline and Bead Testing 


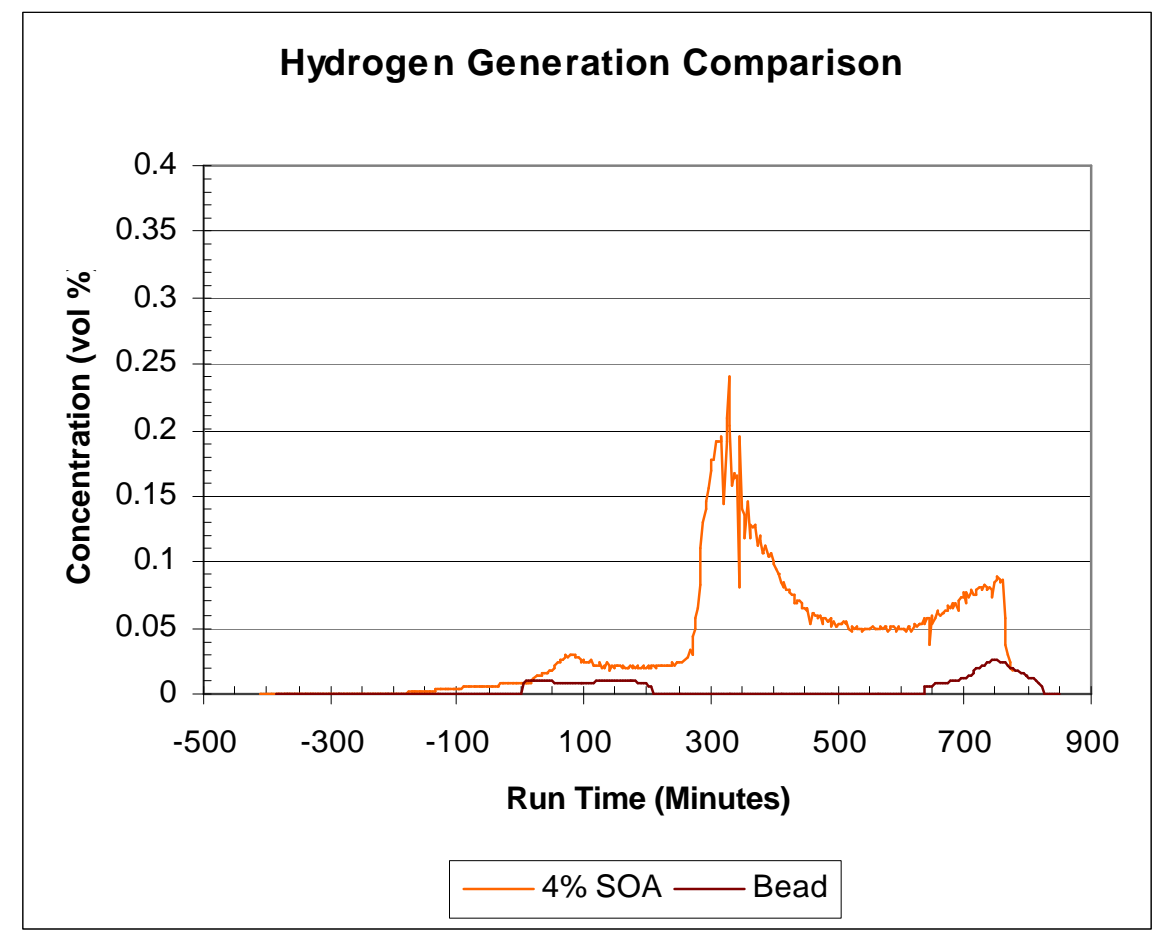

Figure B-3. Hydrogen during SOA 4\% Na and Bead Testing

\section{Carbon Dioxide}

The carbon dioxide peaks during both the bead and frit runs had nearly identical timing, but the bead run results were lower as shown in Figure B-4. The post calibration check on the GC's after the run indicated that the bead run GC was indicating low values for the carbon dioxide, which likely explains the difference in peak amounts. The frit run was used for comparison to the SOA run for this reason. As shown in Figure B-5, the results for the frit run match the SOA baseline run very well. When hydrogen is plotted with $\mathrm{CO}_{2}$, the timing of the peaks matches well, as shown in Figure B-6 for the bead run. 


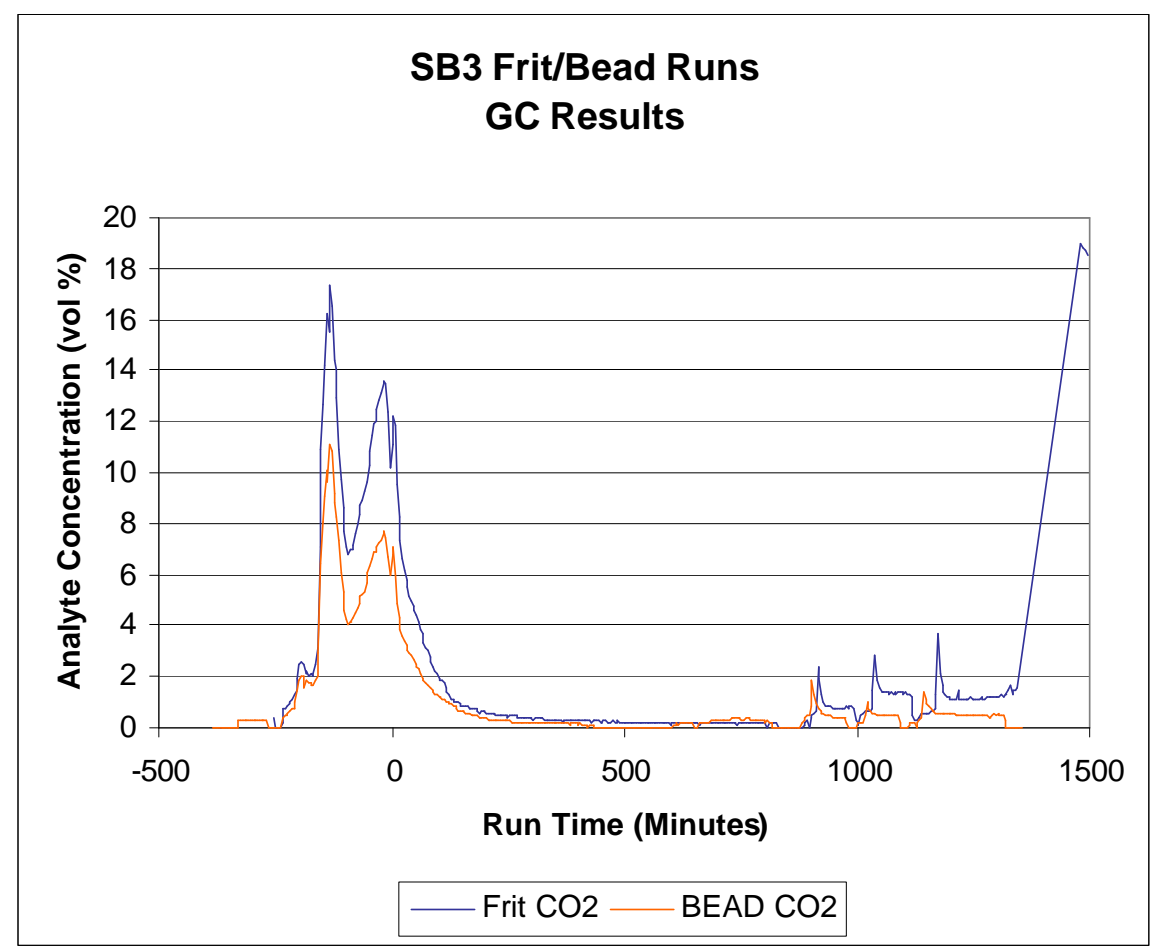

Figure B-4. Carbon Dioxide during Frit/Bead Runs

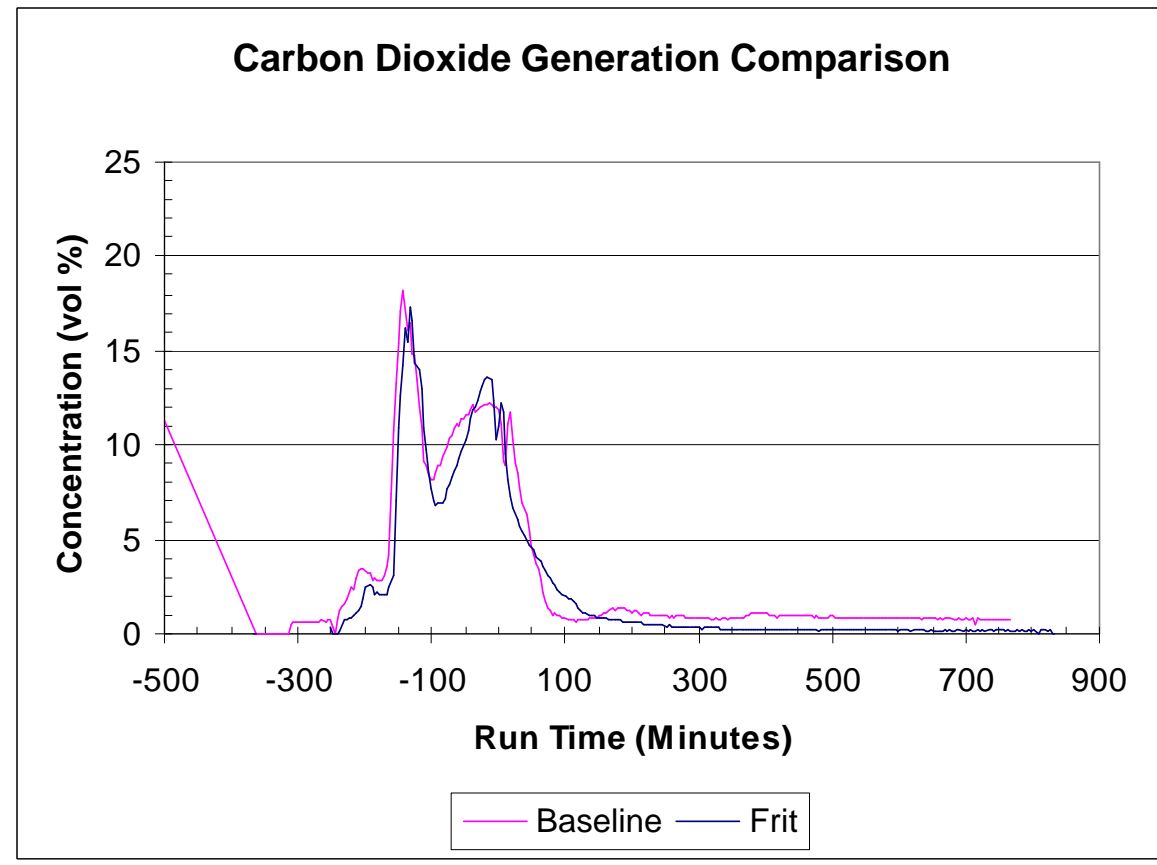

Figure B-5. Comparison of Frit Run Results with SOA Baseline Run 


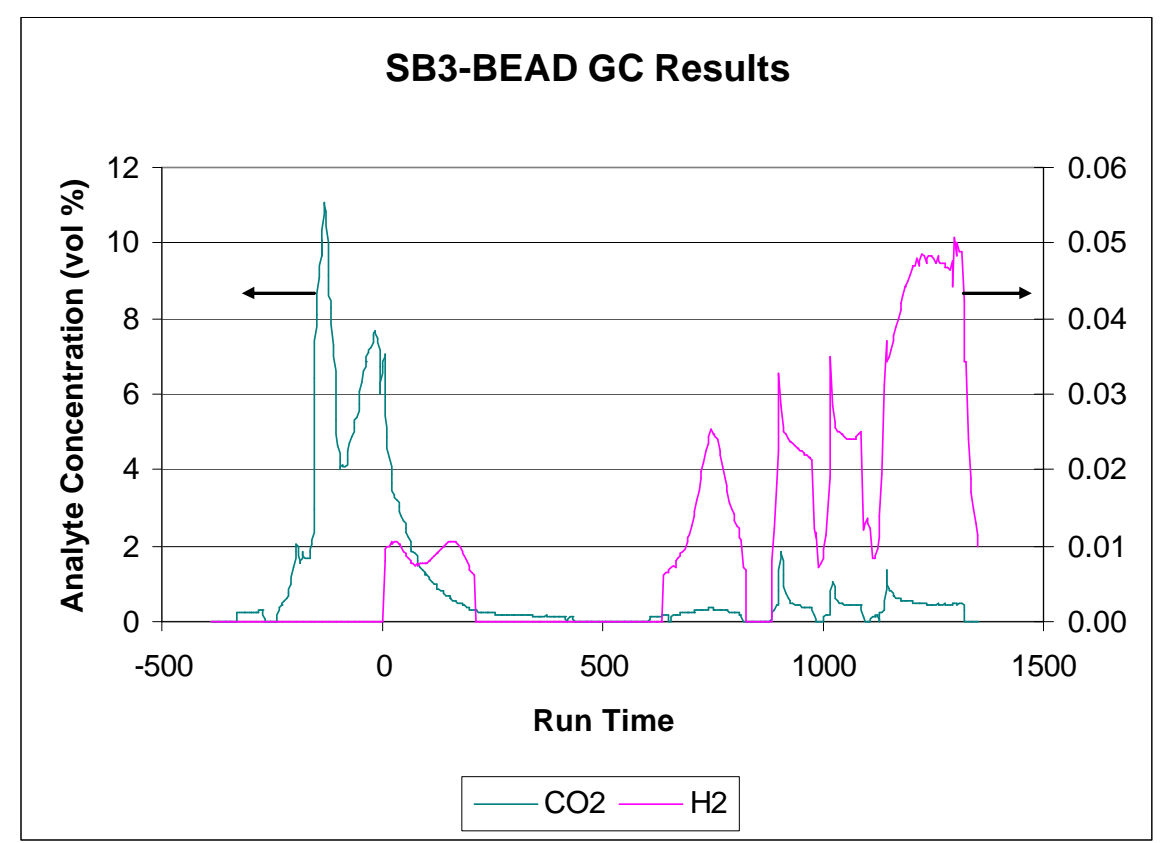

Figure B-6. Comparison of Timing of Carbon Dioxide and Hydrogen Peaks

\section{Other Species}

The trends noted in the gas samples for nitrous oxide, nitrogen, oxygen, helium and $\mathrm{NO}_{\mathrm{x}}$ were similar for the two SRAT/SME cycles conducted during this testing. The results also matched the concentrations during the SOA baseline run. Charts for these species are shown in Figures B-7 to B-13.

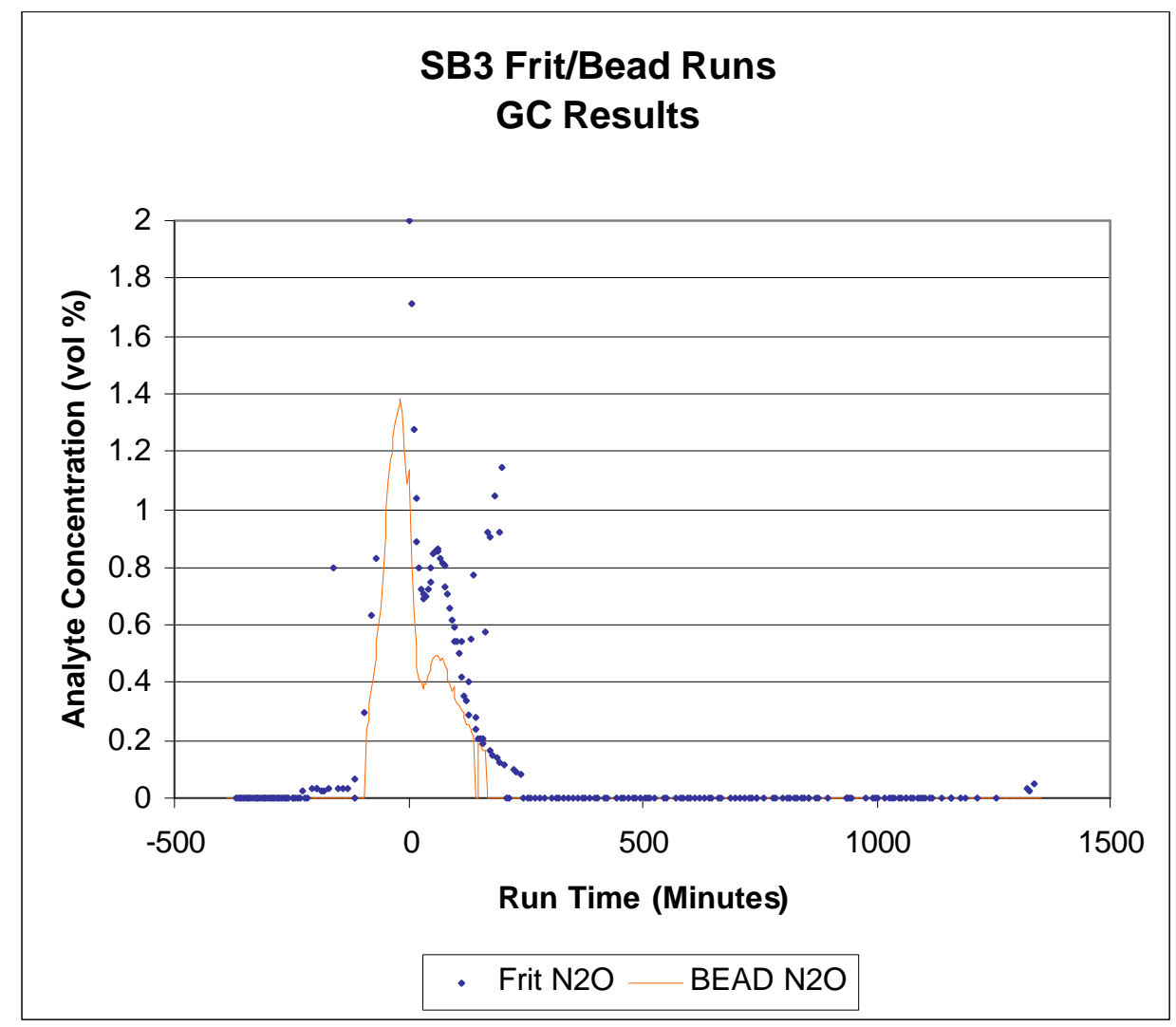

Figure B-7. Nitrous Oxide Concentration during SRAT/SME Cycles 


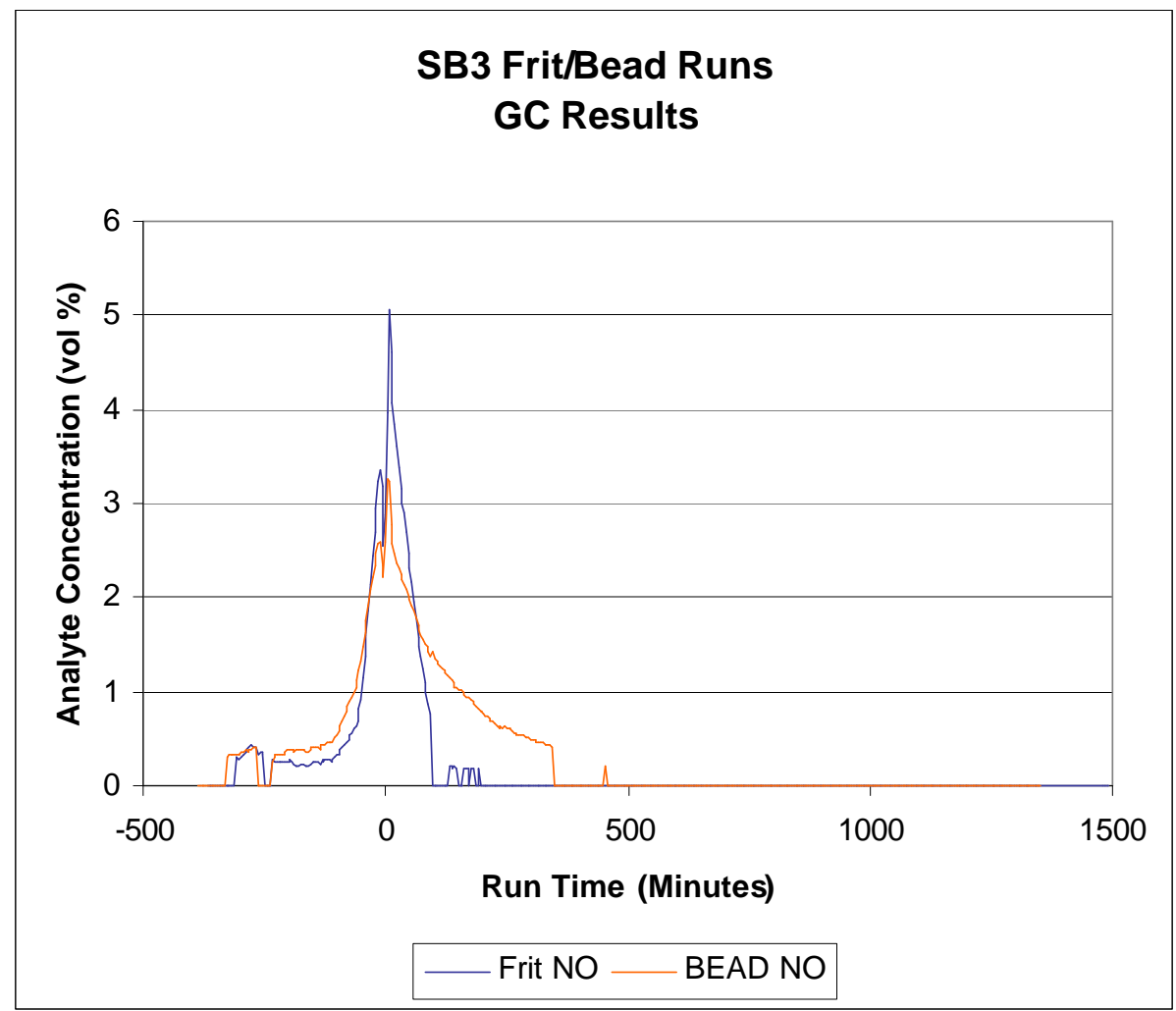

Figure B-8. NOx Concentration during SRAT/SME Cycles

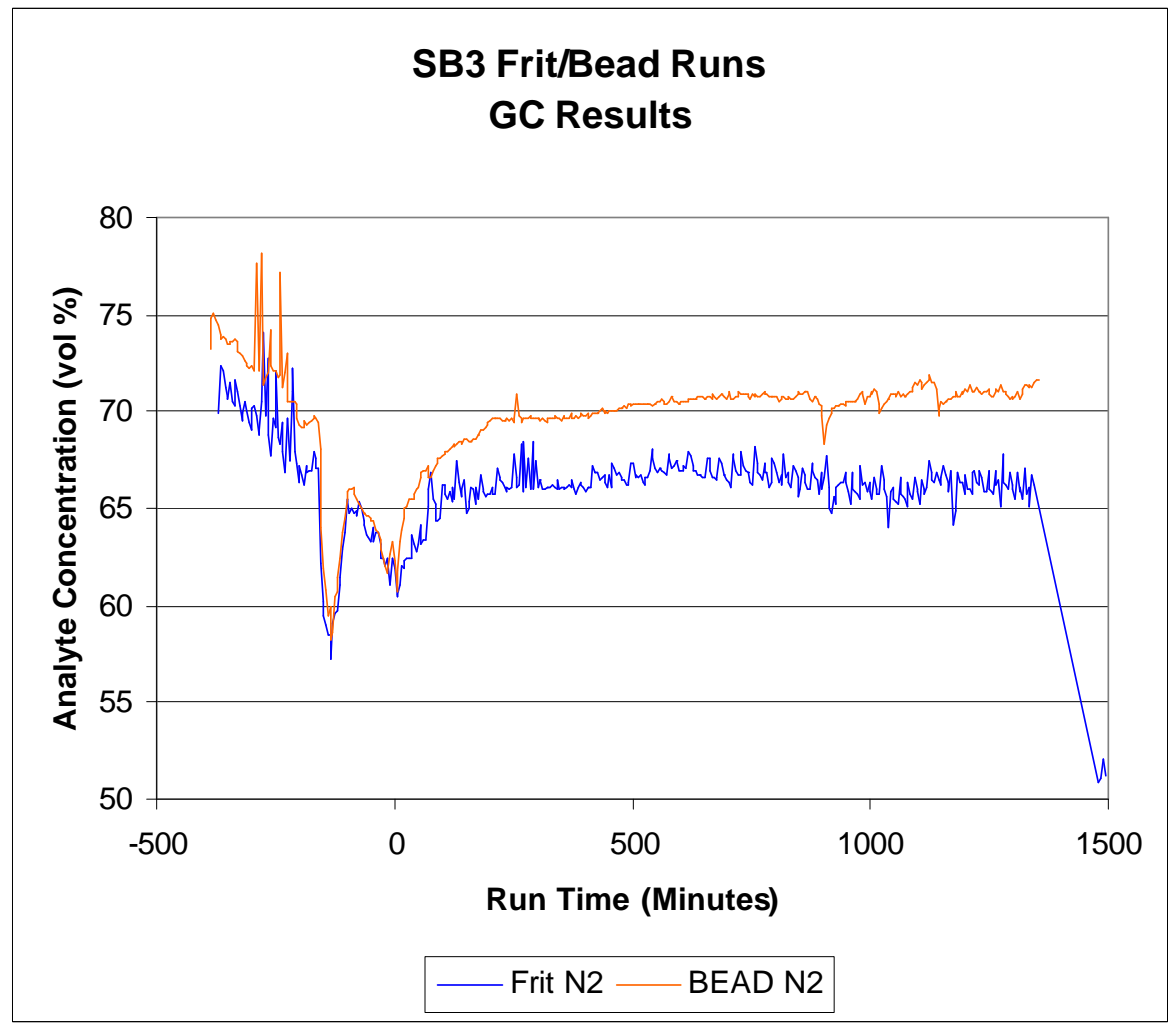

Figure B-9. Nitrogen Concentration during SRAT/SME Cycles 


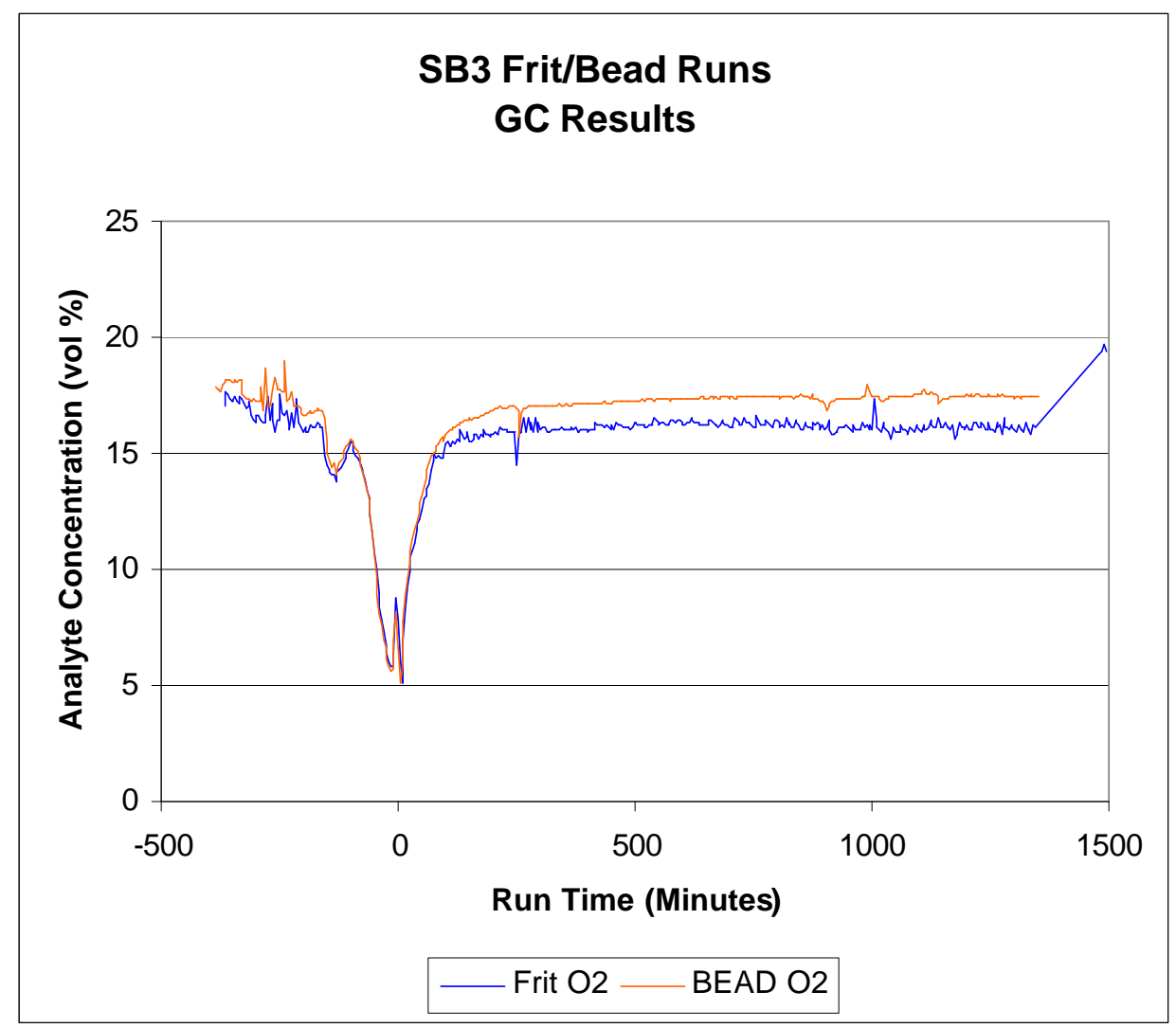

Figure B-10. Oxygen Concentration during SRAT/SME Cycles

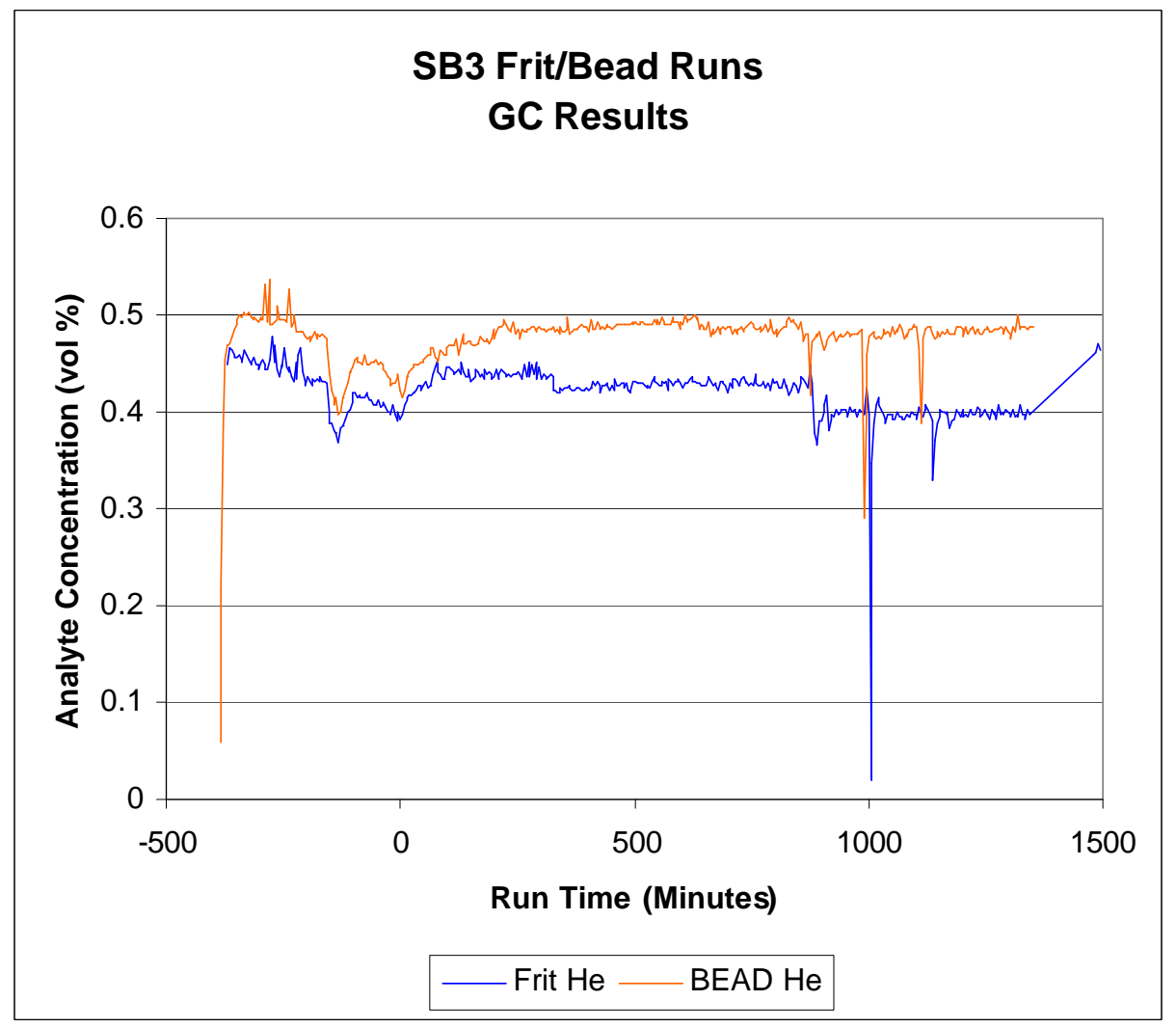

Figure B-11. Helium Concentration during SRAT/SME Cycles 


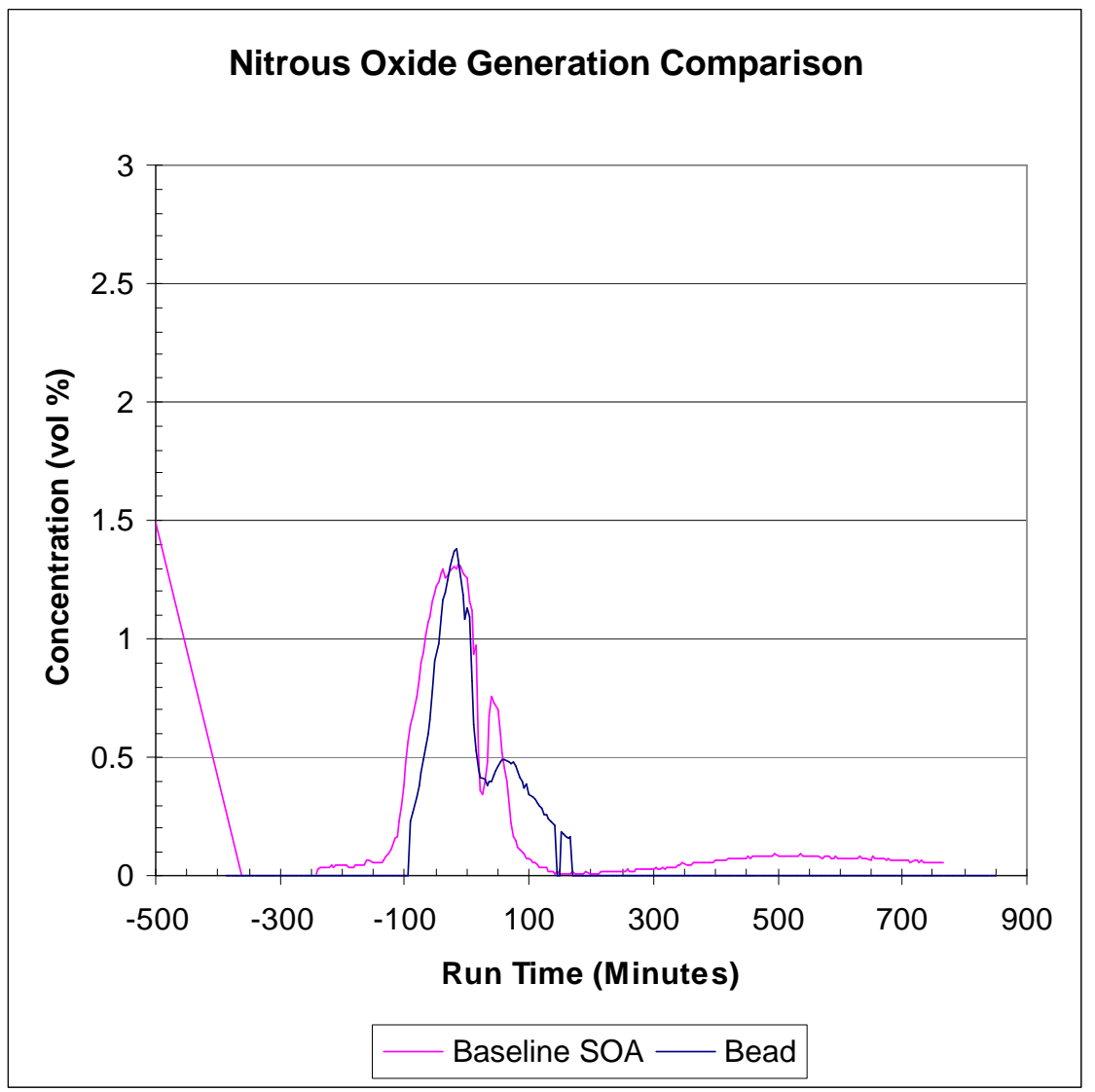

Figure B-12. Nitrous Oxide Comparison to Baseline SOA Tests

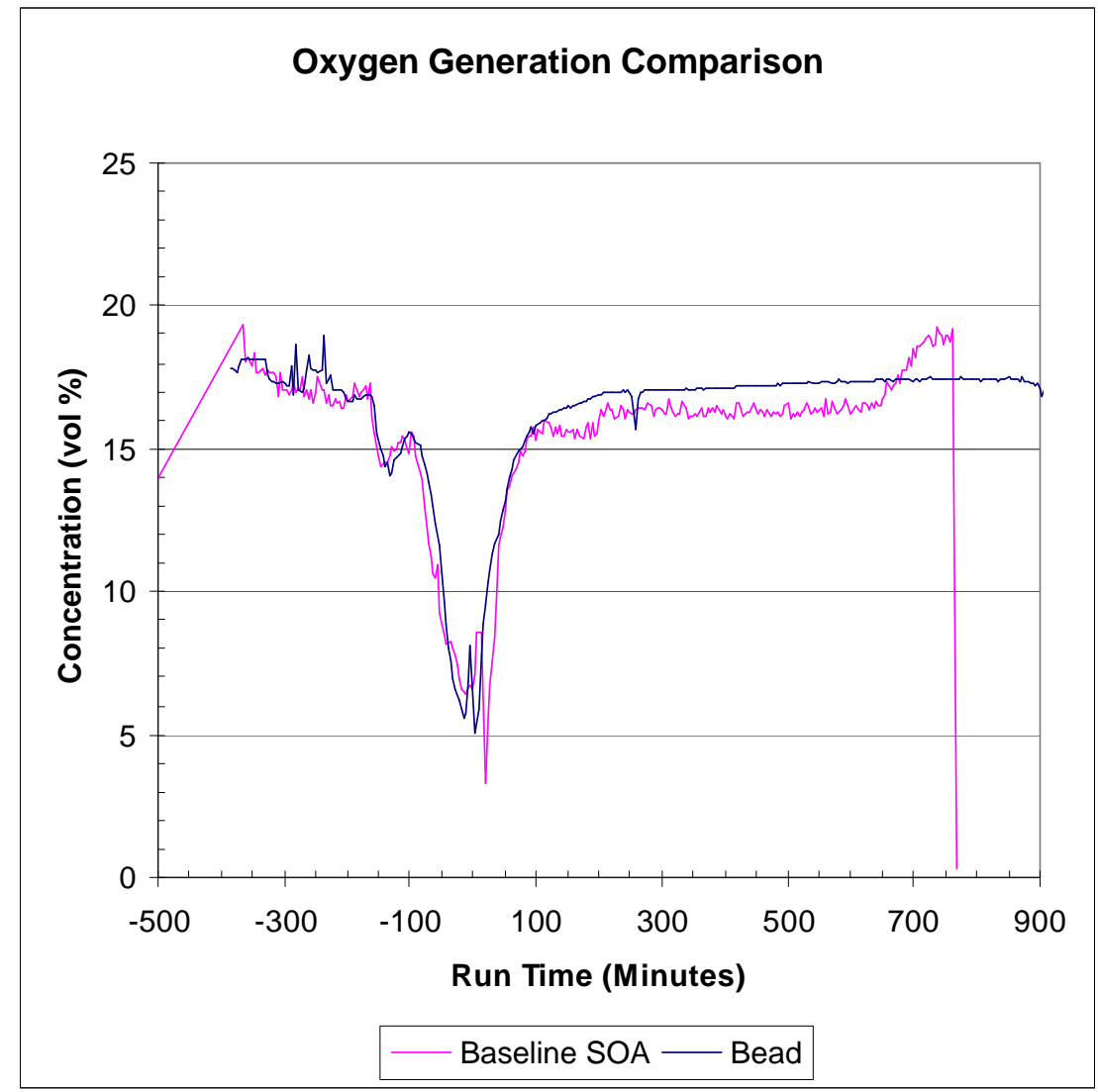

Figure B-13. Oxygen Comparison to Baseline SOA Tests 


\section{Distribution:}

J. E. Marra, SRNL

R. E. Edwards, SRNL

N. E. Bibler, SRNL

C. M. Jantzen, SRNL

G. C. Wicks, SRNL

T. L. Fellinger, SRNL

D. A. Crowley, 999-W

S. L. Marra, 999-W

T. B. Calloway, 999-W

J. R. Harbour, 773-42A

C. A. Langton, 773-43A

M. E. Smith, 999-W

D. H. Miller, 999-W

T. M. Jones, 999-W

D. K. Peeler, 999-W

C. C. Herman, 773-42A

M. E. Stone, 999-W

A. S. Choi, 773-42A

M. S. Miller, 704-S

A. B. Barnes, 704-30S

J. E. Occhipinti, 704-S

R. M. Hoeppel, 704-27S

J. F. Iaukea, 704-30S

D. C. Iverson, 704-30S

R. J. O'Driscoll, 704-30S

J. W. Ray, 704-S 